\title{
H/D Exchange Kinetics: Experimental Evidence for Formation of Different b Fragment Ion Conformers/Isomers During the Gas-Phase Peptide Sequencing
}

\author{
Alireza Fattahi, ${ }^{*}$ Behrooz Zekavat, and Touradj Solouki \\ Department of Chemistry, University of Maine, Orono, Maine, USA
}

Electrospray ionization (ESI) Fourier transform ion cyclotron resonance mass spectrometry (FT-ICR MS) combined with H/D exchange reactions was utilized to explore the existence of different $\mathrm{b}_{5}{ }^{+}$and $\mathrm{b}_{4}{ }^{+}$fragment ion conformers/isomers of hexapeptide WHWLQL in the gas phase. Distinct H/D exchange trends for protonated WHWLQL $\left([\mathrm{M}+\mathrm{H}]^{+}\right)$and $i t s b_{5}{ }^{+}$and $\mathrm{b}_{4}{ }^{+}$fragment ions (with $\mathrm{ND}_{3}$ ) were observed. Isolated ${ }^{12} \mathrm{C}_{\text {all }}$ isotopomers of both $\mathrm{b}_{5}{ }^{+}$and $\mathrm{b}_{4}{ }^{+}$ fragment ions yielded bimodal distributions of H/D exchanged product ions. The H/D exchange reaction kinetics also confirmed that $\mathrm{b}_{5}{ }^{+}$and $\mathrm{b}_{4}{ }^{+}$fragment ions exist as combination of slow-exchanging (" $\mathrm{s}$ ") and fast-exchanging (" $\mathrm{f}$ ") species. The calculated rate constant for the first labile hydrogen exchange of $\left[\mathrm{M}+\mathrm{H}^{+}\left(\mathrm{k}_{[\mathrm{M}}+\mathrm{H}^{+}=3.80 \pm 0.7 \times 10^{-10} \mathrm{~cm}^{3} \mathrm{~mol}^{-1} \mathrm{~s}^{-1}\right)\right.$ was $\sim 30$ and $\sim 5$ times greater than those for the " $\mathrm{s}$ " and " $\mathrm{f}$ " species of $\mathrm{b}_{5}{ }^{+}$, respectively. Data from $\mathrm{H} / \mathrm{D}$ exchange of isolated " $\mathrm{s}$ " species at longer $\mathrm{ND}_{3}$ reaction times confirmed the existence of different conformers or isomers for $\mathrm{b}_{5}{ }^{+}$fragment ions. The sustained off-resonance irradiation collision-activated dissociation (SORI-CAD) of WHWLQL combined with the H/D exchange reactions indicate that " $\mathrm{s}$ " and " $\mathrm{f}$ " species of $\mathrm{b}_{5}{ }^{+}$and $\mathrm{b}_{4}{ }^{+}$fragment ions can be produced in the ICR cell as well as the ESI source. The significance of these observations for detailed understanding of protein sequencing and ion fragmentation pathways is discussed. (J Am Soc Mass Spectrom 2010, 21, 358-369) (c) 2010 Published by Elsevier Inc. on behalf of American Society for Mass Spectrometry

$\mathrm{E}$ lectrospray ionization mass spectrometry (ESI MS) is a powerful tool to monitor various conformations of peptides and proteins [1-12]. The goal of this study was to utilize gas-phase hydrogen/deuterium $(\mathrm{H} / \mathrm{D})$ exchange reactions and Fourier transform ion cyclotron resonance (FT-ICR) mass spectral methods (e.g., multistage ion isolation and ion dissociation) to investigate the existence of different gas-phase fragment ion conformers/isomers.

One of the most important advantages of the modern biological mass spectral techniques is that mass spectrometry can be used for rapid sequencing of biopolymers, such as peptides and proteins, in the gas phase. There are various ion fragmentation techniques that can be used to acquire protein and peptide sequences. A common FT-ICR ion fragmentation technique is sustained off-resonance irradiation collision-activated dissociation (SORI-CAD) [13] (commonly known as collisionally induced dissociation or CID). Recently, other valuable techniques, such as electron capture dissociation (ECD), have been developed to acquire comple-

Address reprint requests to Dr. T. Solouki, Department of Chemistry, University of Maine, Orono, ME 04469, USA. E-mail: solouki@maine.edu

* Current address: Department of Chemistry, Sharif University of Technology, P.O. Box, 11365-9516, Tehran, Iran. mentary fragment ions for more complete sequencing of biomolecules [14]. Regardless of the dissociation techniques employed, successful sequencing of the biological molecules requires detailed understanding of the fragmentation mechanisms and pathways.

Most commonly observed species in SORI-CAD spectra of protonated peptides and proteins include backbone $\mathrm{b}$ and $\mathrm{y}$ type fragment ions $(\mathrm{b}$ and $\mathrm{y}$ fragment ion assignments are according to the Roepstorff nomenclature [15]). During the CID process, the ionized species that yield sequence specific amide-bond fragment ions may undergo rearrangement processes such as cyclization; hence, potential subsequent cycle openings can result in scrambling of the original sequence information [16, 17] and loss of internal residues [18]. Therefore, full characterization of the mechanistic details of ion fragmentation pathways can reduce the chances of erroneous protein sequence identification in proteomics.

A large variety of experimental and theoretical studies have focused on determining the details of fragmentation processes and different mechanisms and pathways for the formation of $b$ and/or $y$ fragment ions have been proposed. The proposed mechanism by Hunt and coworkers for formation of the five-membered cyclic b fragment ions [19] was first supported by the 
reported theoretical calculations of Yalcin et al. [20, 21]. The first theoretical evidence for the formation of $b$ ions having a stable oxazolone structure addressed the energetics of ion dissociation processes and the formation of oxazolone ring from an amide nitrogen in protonated species of a dipeptide [22]. Additional experimental and theoretical data support the importance of these fivemembered ring species in unimolecular peptide fragmentation processes [23, 24].

On the other hand, the involvement of stable aziridinone-containing structures in the gas-phase fragmentation of peptides has also been demonstrated experimentally [25] and theoretically [26]. Wesdemiotis and coworkers' reports provide a comprehensive review on dissociation of the protonated peptide amide bonds that yield $\mathrm{N}$-terminal $\mathrm{b}_{\mathrm{n}}$ and C-terminal $\mathrm{y}_{\mathrm{n}}$ sequence ions $[27,28]$. The combined quantum chemical and RRKM modeling of the $\mathrm{b}$ and $\mathrm{y}$ fragmentation mechanisms of protonated model peptides by Paizs and Suhai provides valuable atomic and energetic details for different reaction pathways that may lead to formation of various fragment ions [24, 29, 30]. Multiple reaction mechanisms such as diketopiperazine, oxazolone, amide $\mathrm{O}$, $\mathrm{a}_{1}-\mathrm{y}_{\mathrm{x}}$, aziridinone pathways [29], and cyclization [18, 31, 32] imply ion fragmentation via multiple pathways. On the other hand, common reaction pathways have also been suggested for different fragment ions. For example, the ' $b_{x}-y_{z}$ ' pathway proposed by Paizs and Suhai assumes common intermediates for the formation of $b_{x}$ and $\mathrm{y}_{\mathrm{z}}$ ions [24]. A comprehensive review on the energetic and kinetic characterization of major fragmentation pathways provides details on "pathways in competition (PIC)" and "mobile proton" models [33].

Our preliminary report demonstrated the presence of different fragment ion isomers and/or conformers in the gas-phase MS/MS experiments [34]. Subsequent reports, utilizing ion mobility/mass spectrometry [32, 35] and infrared multiple-photon dissociation (IR-MPD) [36] confirmed our initial observation and the existence of different isobaric peptide ion fragment isomers. Both IR depletion spectrum [36] and cross-section results from ion mobility/mass spectrometry [32, 35] of Leuenkephalin $\mathrm{b}_{4}{ }^{+}$fragment combined with theoretical approaches have shown a mixture of at least two structurally different $\mathrm{b}_{4}{ }^{+}$and $\mathrm{a}_{4}{ }^{+}$fragments in the fragmentation process of singly-charged Leu-enkephalin ions. In a recent study, Chen et al. reported similar bimodal distributions in the $H / D$ exchange reactions for $b_{4}$ fragments of Leu-enkephalin, $b_{5}$ fragment of $(\mathrm{Gly})_{5}$, and $b_{4}-b_{7}$ fragments of $(G l y)_{8}$ and suggested oxazolone and cyclic structures for b-type fragments [31].

In this paper, we present our experimental evidence that points to the formation of structurally different isobaric $b$ fragment ions in the gas phase and under low-energy SORI-CAD conditions. Specifically, the $\mathrm{H} / \mathrm{D}$ exchange results for the $[\mathrm{M}+\mathrm{H}]^{+}, \mathrm{b}_{5}{ }^{+}$, and $\mathrm{b}_{4}{ }^{+}$ fragment ions of WHWLQL are discussed. FT-ICR MS provides an opportunity to trap and study the peptide ions for extended periods and it is well suited to monitor gas-phase $\mathrm{H} / \mathrm{D}$ exchange reactions for periods ranging from millisecond to several minutes [12]. The $\mathrm{H} / \mathrm{D}$ exchange trends and kinetics reveal the presence of two different sets of $b$ fragment ion isomers and/or conformers in the gas phase. In contrast to $[\mathrm{M}+\mathrm{H}]^{+}$ ions, both $b_{5}{ }^{+}$and $b_{4}{ }^{+}$fragment ions of WHWLQL react with $\mathrm{ND}_{3}$ reagent gas to yield bimodal product ion distributions. Methods to confirm the existence of different gas-phase isobaric fragment ions (i.e., fragment ions with identical elemental compositions) are presented. Relevance of the current experimental findings to mass spectral peptide and protein sequencing is discussed.

\section{Experimental}

\section{Sample Preparation}

The linear hexapeptide WHWLQL (Sigma, St. Louis, $\mathrm{MO}, \mathrm{USA}$ ), deuterium reagent $\mathrm{ND}_{3}$ (Aldrich, Milwaukee, WI, USA) and all other solvents were purchased from commercial sources and used without further purification. A stock solution of WHWLQL was prepared by dissolving $1 \mathrm{mg}$ of the sample in 50:50 methanol: water solution $(1 \mathrm{mg} / \mathrm{mL}, \sim 0.5 \%$ acetic acid). Prior to electrospray, the stock solution of the WHWLQL was diluted to micromolar concentration.

We chose WHWLQL because (1) in our previous studies, it has shown significant metal-dependent conformational changes [37], and the presence of two tryptophans in its structure makes it suitable for gasand solution-phase spectroscopic studies [38], and (2) it is a relatively small peptide (with six amino acids) and appropriate for characterization of fragmentation mechanisms and future molecular modeling studies [39]. We have studied the gas-phase H/D exchange trends and kinetics as well as solution-phase fluorescence characteristics of WHWLQL and its metal complexed species extensively, and these results will be published in a separate article.

\section{Instrumentation}

The ESI FT-ICR mass spectra were acquired with an IonSpec FT-ICR mass spectrometer equipped with a $7 \mathrm{~T}$ superconducting magnet (former IonSpec Corp., now a division of Varian, Inc., Lake Forest, CA, USA). The instrumental details have been published elsewhere [12, 40]. The UHV pressure was measured from the direct readouts using Granville-Philips dual ion gauge controller and series 274 Bayard-Alpert type ionization gauge tubes (Boulder, CO, USA); the normal background pressure inside the ICR cell was $\sim 5 \times 10^{-10}$ torr. Ions were formed in an external ionization electrospray source (Analytica of Branford, Inc., Branford, CT, USA).

Typically, $2.0 \mathrm{kV}$ was applied to the ESI needle, (with respect to the counter electrode capillary), and the metal capillary temperature was set at $\sim 160 \pm 2{ }^{\circ} \mathrm{C}$. The 
electrosprayed ions pass through a $1 \mathrm{~mm}$-diameter skimmer before their entrance into a $7.5-\mathrm{cm}$ long, $\mathrm{rf}-$ only hexapole ion guide/storage device. A quadrupole ion guide assembly guides the ions into an open-ended cylindrical Penning trap (former IonSpec Corp., now a division of Varian, Inc., Lake Forest, CA, USA). Appropriate timing and gated trapping techniques were used to trap the ions inside the ICR cell. After the ions were trapped inside the ICR cell a variable delay period $(<50$ s) was allowed for restoration of base pressure. Once the ions were trapped inside the ICR cell, a combination of "CHIRP" frequency sweep [41] and SWIFT dipolar excitation [42] was used to isolate a specific ion or a set of ions. Before H/D exchange reactions, trapped ions were thermalized by nitrogen collisions. Multiple pulses of nitrogen gas, through a designated vacuum port, were used to maintain $\mathrm{P}_{\mathrm{N} 2} \cong 1 \times 10^{-6}$ torr for $\sim 50$ to 2000 ms during the ion cooling event. The residual nitrogen gas was pumped away before all SWIFT isolations and H/D exchange reactions. The H/D exchange reaction time was varied to follow the kinetics of isotope exchange. To ensure prolonged pressure reproducibility inside the ICR cell during the reaction of precursor ions with $\mathrm{ND}_{3}$, the neutral $\mathrm{H} / \mathrm{D}$ exchange $\mathrm{ND}_{3}$ reagent gas was introduced into the vacuum system through a separate port via a pulsed-leak valve [43]. The pressure of $\mathrm{ND}_{3}$ was measured by direct reading of Granville-Philips dual ion gauge controller and series 274 Bayard-Alpert type ionization gauge tubes and corrected for ionization sensitivity [44]. Under our experimental reaction times and pressures, no $\mathrm{ND}_{3}$ clusters [45] were observed with protonated hexapeptide and its fragment ions. Since our goal was to compare the rate constants for parent ions and b-type fragments under identical conditions, the pressure of $\mathrm{ND}_{3}$ was not corrected for the geometry factor of 0.55 [44]. The trapped product ions were excited by dipolar frequency sweep excitation [41] and detected in the direct broadband mode. At the end of each experiment, all trapped ions were ejected from the ICR cell. Fourier transformation of the resulting time-domain signals (256 k data points) with one zero-fill, baseline correction and Hamming apodization followed by magnitude calculation, and frequency-to-mass conversion yielded the ESI FT-ICR mass spectra (Figures 1, 2, and Figures 4-6). All mass spectra were constructed from a single time-domain dataset. To perform reproducible gas-phase H/D exchange experiments, the ESI conditions (e.g., source temperature, ion current, acceleration voltages, etc.) were carefully monitored and kept constants for all experiments.

\section{Mass Spectral Data Analysis}

The plots of $\ln \left(\operatorname{Im}_{\mathrm{i}} / \Sigma \mathrm{Im}_{\mathrm{i}}\right)$ as a function of reaction time were constructed. The equation describing these plots can be written as:

$$
\ln \left(\operatorname{Im}_{\mathrm{i}} / \Sigma \operatorname{Im}_{\mathrm{i}}\right)=-\mathrm{k} \times[\mathrm{M}] \times \mathrm{t}+\mathrm{C}
$$

where $\left(\operatorname{Im}_{\mathrm{i}} / \Sigma \operatorname{Im}_{\mathrm{i}}\right)$ is the normalized intensity of the precursor ion, $\mathrm{k}$ is the reaction rate constant, $[\mathrm{M}]$ is the concentration of neutral species $\left(\mathrm{ND}_{3}\right)$, $\mathrm{t}$ is the reaction time, and $C$ is a constant [46]. The normalized ion intensity value for each species (e.g., $[\mathrm{M}+\mathrm{H}]^{+}, \mathrm{b}_{4}{ }^{+}$, and $b_{5}{ }^{+}$) was obtained by dividing the $\mathrm{D}_{0}$ peak intensity of each group (e.g., $\mathrm{H} / \mathrm{D}$ exchanged $[\mathrm{M}+\mathrm{H}]^{+}$series) by the total peak intensity of that particular group (i.e., $\mathrm{D}_{0}+\mathrm{D}_{1}+\ldots+\mathrm{D}_{\mathrm{n}}, n=1-14$ for the $[\mathrm{M}+\mathrm{H}]^{+}$series) at different reaction times. To minimize the pressure and/or temperature variations, we isolated all of the precursor species and followed their H/D exchange reaction kinetics simultaneously. The linear regression of the slope of equation 1 (i.e., $-k \times[M]$ ) versus $[\mathrm{M}]$ yields $R^{2} \approx 0.99$ and the slope provides a better estimation of the $\mathrm{k}$. Based on five experiments performed at five different pressures for each species, rate constants reported in this paper have an estimated random experimental error of $<25 \%$. The experimental errors are mainly due to pressure variations for different experiments. To generate the decay curves in Figure 3a-c, Origin 7.0 (Northampton, MA, USA) software (ver. 7.0220) was used; the reported uncertainties for time constant $(\tau)$ and pre-exponential values are from the nonlinear curve fit outputs. Microsoft excel linear regression was used to determine the values for line slopes, intercepts, and associated uncertainties (inserts in Figure 3a-c).

\section{Results and Discussion}

To explore the existence of structurally different isobaric fragment ions, we followed the gas-phase H/D exchange reactions of the WHWLQL hexapeptide and its $\mathrm{b}_{5}{ }^{+}$and $\mathrm{b}_{4}{ }^{+}$fragment ions. This peptide dissociates to yield high abundance of $b$ series fragment ions.

$\mathrm{ND}_{3}$ was used for all $\mathrm{H} / \mathrm{D}$ exchange reactions; this reagent gas is less selective than other $\mathrm{H} / \mathrm{D}$ exchange reagents such as $\mathrm{D}_{2} \mathrm{O}$ and $\mathrm{CH}_{3} \mathrm{OD}$ and allows isotope exchange of all active hydrogens (e.g., proton in $-\mathrm{OH}$, SH, and NH functional groups) [12, 47-49]. Table 1 contains the exact molecular weights (to five significant figures) and calculated rate constants for selected parent and fragment ions (experimental details will be discussed in the next section).

\section{Hydrogen/Deuterium Exchange Patterns}

Figure 1a shows ESI FT-ICR mass spectrum of WHWLQL that contains isolated ${ }^{12} \mathrm{C}_{\text {all }}$ isotopomers of parent molecular ion of the WHWLQL hexapeptide $\left([\mathrm{M}+\mathrm{H}]^{+}\right)$and its $\mathrm{b}_{4}{ }^{+}$and $\mathrm{b}_{5}{ }^{+}$fragment ions. For all experiments reported herein, before starting the $\mathrm{H} / \mathrm{D}$ exchange reactions, the single isotopes $\left({ }^{12} \mathrm{C}_{\text {all }}\right)$ of the precursor ions were SWIFT isolated [42]. The SWIFT isolation of a single isotope eliminates peak overlap 
between the ${ }^{13} \mathrm{C}$ isotopes of the reactant analyte ion and deuterated product species.

Figure $1 \mathrm{~b}$ shows a representative ESI FT-ICR mass spectrum of WHWLQL peptide after the H/D exchange reaction. The $m / z$ range containing $[\mathrm{M}+\mathrm{H}]^{+}, \mathrm{b}_{5}{ }^{+}$, and $\mathrm{b}_{4}{ }^{+}$species after reacting with $\mathrm{ND}_{3}$ at $\sim 6.5 \times 10^{-9}$ torr for $580 \mathrm{~s}$ is shown. The expanded $m / z$ regions for H/D exchanged $[\mathrm{M}+\mathrm{H}]^{+}, \mathrm{b}_{5}{ }^{+}$, and $\mathrm{b}_{4}{ }^{+}$are shown in Figure $2 \mathrm{a}-\mathrm{c}$, respectively. Labeled subscripts $\left(\mathrm{D}_{0}-\mathrm{D}_{9}\right)$ denote the number of incorporated deuterium isotopes. Comparison of Figure 2a-c illustrates the differences in H/D exchange patterns of the parent molecular ion $[\mathrm{M}+\mathrm{H}]^{+}$ (2a), and its $\mathrm{b}_{5}{ }^{+}$and $\mathrm{b}_{4}{ }^{+}$fragment ions (2b and $\mathrm{c}$, respectively). After the $H / D$ exchange reaction with $\mathrm{ND}_{3}$ at $6.5 \times 10^{-9}$ torr for $580 \mathrm{~s}, \mathrm{~b}_{5}{ }^{+}$, and $\mathrm{b}_{4}{ }^{+}$fragment ions yield bimodal distributions of product ions (Figure $2 b$ and $c)$. We have repeated these experiments at different pressures and observed similar bimodal distributions. The observed H/D exchange trends for $\mathrm{b}_{5}{ }^{+}$ and $\mathrm{b}_{4}{ }^{+}$could be indicative of two different conformers and/or isomers that exchange their labile hydrogens at different rates (i.e., slow and fast H/D exchanging fragment ions).

To verify that the observed bimodal distributions (as shown in Figure $2 b$ and $c$ ) are indicative of the two sets of conformers or isomers for $\mathrm{b}_{5}{ }^{+}$and $\mathrm{b}_{4}{ }^{+}$fragment ions, the H/D exchange kinetics of $[\mathrm{M}+\mathrm{H}]^{+}, \mathrm{b}_{5}{ }^{+}$, and $\mathrm{b}_{4}{ }^{+}$ were studied in detail (see Figure 3 and related discussions). Furthermore, additional double SWIFT isolation and double H/D exchange reactions (Figures 4 and 5) were performed to confirm the existence of the two sets of gas-phase isobaric fragment ion species for the $b_{5}{ }^{+}$ fragment ions.

The fragment ions of the WHWLQL hexapeptide can be formed in the ICR cell and/or in the electrospray ionization (ESI) source by the capillary-skimmer fragmentation process. To perform the necessary double SWIFT ion-isolation and double H/D exchange reaction experiments (details will follow), all ICR and ESI source experimental parameters were optimized to maximize the $b$ fragment ion yield and enhance signal-to-noise ratio for single scan experiments (data shown in Figures $1,2,4$, and 5). To confirm the formation of structurally different fragment ions under the low-energy CID conditions of ICR, supplementary experiments were performed. Using SORI-CAD technique [13], we verified that the " $\mathrm{f}$ " and " $\mathrm{s}$ " fragment ions were generated inside the ICR cell as well as in the ESI region (data for Figure 6 will be discussed in detail).

\section{Hydrogen/Deuterium Exchange Reaction Kinetics}

The plots of normalized intensity versus $H / D$ reaction times for $[\mathrm{M}+\mathrm{H}]^{+}, \mathrm{b}_{5}{ }^{+}$, and $\mathrm{b}_{4}{ }^{+}$are shown in Figure 3 . Equations from the exponential curve fittings (viz., $[\mathrm{M}+\mathrm{H}]^{+}, \mathrm{b}_{5}{ }^{+}$, and $\mathrm{b}_{4}{ }^{+}$) are included below each ion abundance decay curve in Figure 3a-c. Figure 3a shows the disappearance of $[\mathrm{M}+\mathrm{H}]^{+}$as a function of time and curve fitting of the raw data yields a single expo- nential decay with a pre-exponential value of 1.1 $( \pm 0.04)$ and time constant of $\tau=21( \pm 1.9) \mathrm{s}$.

Figure $3 \mathrm{~b}$ and c correspond to disappearances of isolated ${ }^{12} \mathrm{C}_{\text {all }}$ species for $\mathrm{b}_{5}{ }^{+}$and $\mathrm{b}_{4}{ }^{+}$fragment ions $\left(\mathrm{D}_{0}\right.$ peaks at $m / z 751$ and 623 in Figure 2 ) as a function of time. Curve fittings of the raw data yielded bi-exponential decay equations for both $\mathrm{b}_{5}{ }^{+}$and $\mathrm{b}_{4}{ }^{+}$fragment ions (sum of the pre-exponential values were constrained to $\left.1\left\{A_{1}+A_{2}=1\right\}\right)$. For $b_{5}{ }^{+}$fragment ions, pre-exponential values were $\mathrm{A}_{1}=0.62( \pm 0.02)$ for $\tau_{1}=43( \pm 3.5) \mathrm{s}$ and $\mathrm{A}_{2}=0.38( \pm 0)$ for $\tau_{2}=395( \pm 0) \mathrm{s}$. These pre-exponential values represent all of the available reaction channels that yield $D_{1}$ species and do not necessarily correlate with ion population fractions for slow ("s") and fast (" $\mathrm{f}$ ") $\mathrm{H} / \mathrm{D}$ exchanging species. For example, the two reaction rate constants of $(7.7 \pm 1.5) \times 10^{-11}$ and $(1.3 \pm$ $0.3) \times 10^{-11} \mathrm{~cm}^{3}$ molecule ${ }^{-1} \mathrm{~s}^{-1}$ for " $\mathrm{f}$ " and " $\mathrm{s}$ " $\mathrm{b}_{5}{ }^{+}$ species, respectively, represent the average rate constants for all of the available exchanging sites. In other words, separation of the two " $\mathrm{s}$ " and " $\mathrm{f}$ " populations is not controlled by the first $H / D$ exchange (i.e., $D_{0} \rightarrow D_{1}$ ) (although it represents the $H / D$ exchange reaction of two different $b$ fragment structures).

As shown in the ln (normalized abundance) versus $\mathrm{H} / \mathrm{D}$ exchange reaction time semilog plots displayed in the insets of Figure $3 b-c$, compared with $[\mathrm{M}+\mathrm{H}]^{+}$ (Figure 3a), the $\mathrm{b}_{5}{ }^{+}$and $\mathrm{b}_{4}{ }^{+}$fragment ions exhibit two distinct slopes (Figure $3 b$ and $c$, respectively). The slope, intercept, and square of correlation coefficient $\left(\mathrm{R}^{2}\right)$ for linear regression of the temporal semilog plot for $[\mathrm{M}+\mathrm{H}]^{+}$in Figure 3a (inset) are $\mathrm{m}=-0.063$ $( \pm 0.003) \mathrm{s}^{-1}, \mathrm{~b}=0.20( \pm 0.08)$, and $\mathrm{R}^{2}=0.99$. The best fit single decay curve (using Origin software) for [M + $\mathrm{H}]^{+}$in temporal plot of Figure 3a corresponds to the best fit single line (using Microsoft Excel program) displayed in Figure 3a inset. Conversely, improved $\mathrm{R}^{2}$ for linear regression of the data (using Microsoft Excel program) presented in Figure $3 b$ and $c$ were obtained by using the initial data points (seven in Figure $3 b$ and eight in Figure 3c) as separate lines (for fast reacting species).

Comparisons between Figure $3 a, b$, and c confirm the existence of structurally different conformers and/or isomers for both $b_{5}{ }^{+}$and $b_{4}{ }^{+}$fragment ions: the fast- $\left(b_{5 f}\right.$ and $\left.b_{4 \mathrm{f}}\right)$ and slow-exchanging $\left(b_{5 s}\right.$ and $\left.b_{4 s}\right)$ fragment ions. The fast and slow exchanging species (Figure $3 b-c$, insets) are represented with the filled circle $(0)$ and empty triangle $(\triangle)$ symbols, respectively. The slopes, intercepts, and $\mathrm{R}^{2}$ values from linear regressions of the two lines from the temporal semilog plot data of $\mathrm{b}_{5}{ }^{+}$in Figure $3 \mathrm{~b}$ (inset) are $\mathrm{m}_{\text {fast }}=-0.0139( \pm 0.0004) \mathrm{s}^{-1}$ and $\mathrm{m}_{\text {slow }}=-0.0024( \pm 0.0001) \mathrm{s}^{-1} ; \mathrm{b}_{\text {fast }}=0.0266$ $( \pm 0.0124)$ and $b_{\text {slow }}=-0.98( \pm 0.04) ; R_{\text {fast }}^{2}=0.9955$ and $\mathrm{R}_{\text {slow }}^{2}=0.9905$. The slopes, intercepts, and $\mathrm{R}^{2}$ values from linear regressions of the two lines from the temporal semilog plot data of $\mathrm{b}_{4}{ }^{+}$in Figure 3c (inset) are $\mathrm{m}_{\text {fast }}=-0.0163( \pm 0.0005) \mathrm{s}^{-1}$ and $\mathrm{m}_{\text {slow }}=-0.0019$ $\left( \pm 8 \times 10^{-5}\right) \mathrm{s}^{-1} ; \mathrm{b}_{\text {fast }}=0.059( \pm 0.019)$ and $\mathrm{b}_{\text {slow }}=$ $-1.641( \pm 0.025) ; R_{\text {fast }}^{2}=0.9953$ and $R_{\text {slow }}^{2}=0.9959$. 
The gas-phase H/D exchange rate constants were extracted from the slopes of semilog plots of normalized ion abundance for $D_{0}$ ion as a function of the $H / D$ exchange reaction time (Table 1 ). The calculated rate constants for " $\mathrm{f}$ " species have contributions from " $\mathrm{s}$ " species. Therefore, one can calculate the rate constants for " $\mathrm{f}$ " species more accurately by subtracting the contributions of " $s$ " species from " $\mathrm{f}$ " species at shorter $\mathrm{H} / \mathrm{D}$ exchange reaction times (i.e., <130 s) or use bi-exponential decay equations obtained by fittings (Figure 3). The best experimental approach to calculate population fractions of " $\mathrm{s}$ " and " $\mathrm{f}$ " is to allow for complete separation of the two populations based on reaction times (see Table 1 and discussions below).

Although $\mathrm{D}_{0}$ of the parent molecular ion $[\mathrm{M}+\mathrm{H}]^{+}$is consumed after $\sim 90 \mathrm{~s}$ reaction period (at $9.5 \times 10^{-9}$ torr $\mathrm{ND}_{3}$ pressure), only a single distinct slope is observed for the entire reaction period (e.g., refer to Figure $2 a$ and Figure 3a). The semilog plot in Figure 3a \{ln (normalized abundance) versus the reaction time suggests the presence of a single $[\mathrm{M}+\mathrm{H}]^{+}$conformer or set of $[\mathrm{M}+$ $\mathrm{H}]^{+}$conformers that can not be distinguished/resolved using the currently available FT-ICR methodologies. Conversely, the plots of $\ln$ (normalized abundance) versus the reaction time for b-series fragment ions (Figure $3 b$ and c) exhibit two distinct slopes; hence, the first $H / D$ exchange of these species occur at two different reaction rates. Using the Microsoft Excel program (Microsoft Office Excel 2000) linear regression analyses were performed to determine the best linear fits to the experimental data. For the presented data here, we assumed two ion populations (i.e., two lines) and excluded the data points on the curved segment of the semilog plots (data points in insets of Figure $3 \mathrm{~b}$ and $c$ denoted with [-] symbol). Experimental data from other fragment ions (not shown here) indicate that when more than two ion populations are present, more rigorous curve-fitting routines (e.g., multiple exponential function fittings of the temporal plots) are necessary to extract accurate rate constant values. For the reported data in Figures $3 \mathrm{~b}$ and $\mathrm{c}$, linear fit of the semilog plots provided satisfactory results $\left(\mathrm{R}^{2}>0.99\right.$ for all four fits) and a more rigorous double-exponential curve fitting by including all data points, yielded similar results. The normalized mass spectral data on separated " $\mathrm{f}$ " and " $\mathrm{s}$ " species at long H/D exchange reaction times (i.e., $>130$ s) were used to calculate the average fractions of each species (Table 1). For example, after 580 s H/D exchange reaction time for $\mathrm{b}_{5}{ }^{+}$(Figure $2 b$ ) the sums of the normalized peak intensities (or fractions) for "s" species (viz., $\mathrm{D}_{0}-\mathrm{D}_{2}$ ) and " $\mathrm{f}$ " species (viz., $\mathrm{D}_{3}-\mathrm{D}_{7}$ ) are 0.74 and 0.26 , respectively. Using $b_{5}{ }^{+}$ion population fractions at seven reaction delay times (viz., $180 \mathrm{~s}, 240 \mathrm{~s}, 310 \mathrm{~s}, 390 \mathrm{~s}$, $480 \mathrm{~s}, 580 \mathrm{~s}$, and $700 \mathrm{~s}$ ) yielded average values of 0.73 and 0.27 for slow and fast reacting species, respectively; conversely, factions of slow and fast reacting $\mathrm{b}_{4}^{+}$species were switched (see Table 1). Our preliminary results indicate that ionization/fragmentation condi-

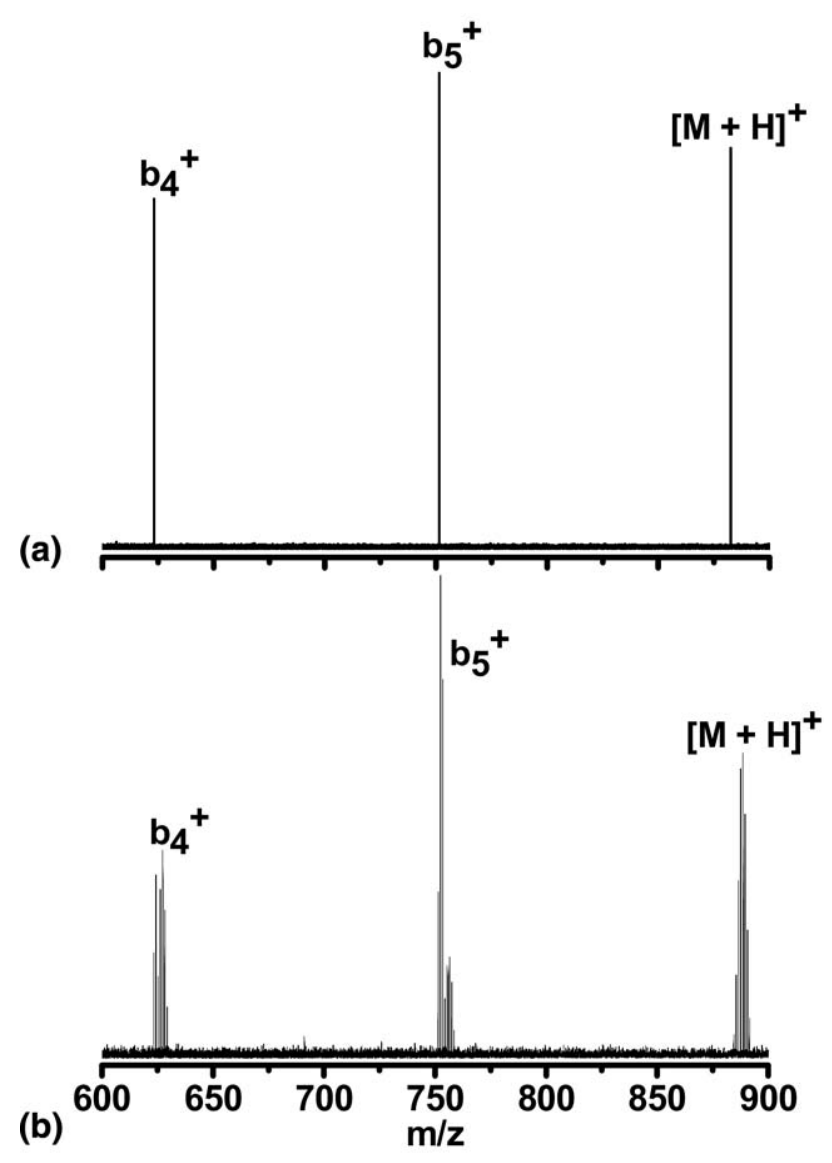

Figure 1. ESI FT-ICR mass spectrum of the SWIFT isolated ${ }^{12} \mathrm{C}_{\text {all }}$ isotopomers for parent molecular ion of WHWLQL hexapeptide: $[\mathrm{M}+\mathrm{H}]^{+}$, its b-series fragment ions: $\mathrm{b}_{5}{ }^{+}$and $\mathrm{b}_{4}{ }^{+}$(a) before the $\mathrm{H} / \mathrm{D}$ exchange reactions and (b) after the H/D exchange reaction with $\mathrm{ND}_{3}$ at $6.5 \times 10^{-9}$ torr for $580 \mathrm{~s}$.

tions influence the formation of slow and fast exchanging populations [50].

The H/D exchange patterns, as shown in Figure 2, portray comprehensive pictures about all of the available exchangeable sites on the molecule. However, the kinetic plots in Figure 3, refer to the fastest H/D exchanging sites for the respective species. Multiple site and/or site specific [4, 47, 51] kinetics can provide valuable structural details. For example, in addition to different $H / D$ exchange reaction rate constants for $[\mathrm{M}+\mathrm{H}]^{+}$and $\mathrm{b}$ fragments in $\mathrm{D}_{0} \rightarrow \mathrm{D}_{1}$ reaction (Figure $3)$, the $H / D$ exchange reaction rate for exchanging the second, third, and other labile hydrogens in the individual species (i.e., $[\mathrm{M}+\mathrm{H}]^{+}$and $b$ fragments) might be different.

Calculated rate constants (for the disappearance of $\left.\mathrm{D}_{0}\right)$ for $[\mathrm{M}+\mathrm{H}]^{+}\left(\mathrm{k}_{[\mathrm{M}+\mathrm{H}]}{ }^{+}\right)$, the slow $\left(\mathrm{k}_{\mathrm{s}}\right)$ and fast $\left(\mathrm{k}_{\mathrm{f}}\right)$ reacting conformers/isomers of $b$ fragments, the rate constant ratios, and the fraction of each species are listed in Table 1. Rate constant for the first $H / D$ exchange of $b_{5 f}{ }^{+}$fragment ion (fast exchanging species) is $\sim$ six times larger than the rate constant for the $\mathrm{b}_{5 \mathrm{~s}}{ }^{+}$; the rate constant for the first $H / D$ exchange for $b_{4 f}{ }^{+}$is 
(a)

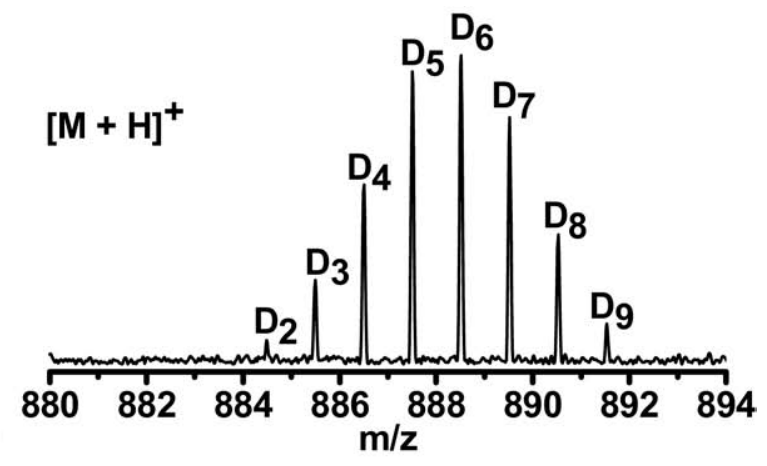

(b)

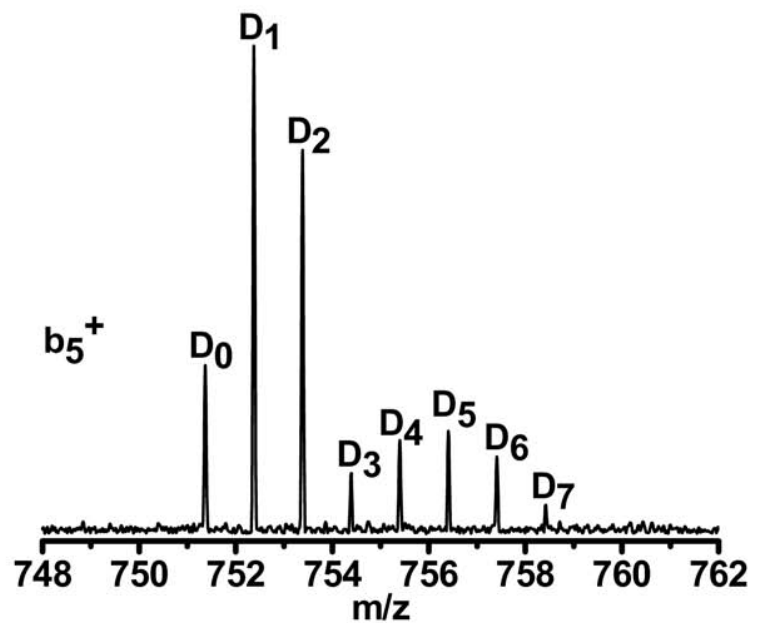

(c)

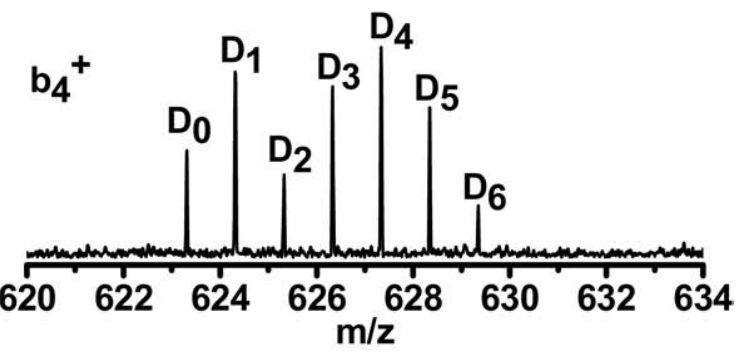

Figure 2. Expanded $\mathrm{m} / \mathrm{z}$ regions of $\mathrm{H} / \mathrm{D}$ exchange spectrum (from Figure $\mathbf{1 b}$ ) for $(\mathbf{a})[\mathrm{M}+\mathrm{H}]^{+},(\mathbf{b}) \mathrm{b}_{5}{ }^{+}$, and (c) $\mathrm{b}_{4}{ }^{+}$species.

$\sim$ eight times larger than that for the $\mathrm{b}_{4 \mathrm{~s}}{ }^{+}$species. The $\mathrm{H} / \mathrm{D}$ exchange results for the slow exchanging fragment ions (i.e., $\mathrm{b}_{5 \mathrm{~s}}{ }^{+}$and $\mathrm{b}_{4 \mathrm{~s}}{ }^{+}$) and fast exchanging species (i.e., $b_{5 f}{ }^{+}$and $b_{4 f}{ }^{+}$) suggest that the fragmentation process of $[\mathrm{M}+\mathrm{H}]^{+}$produces a mixture of at least

Figure 3. Temporal plots of normalized ion abundance versus $H / D$ exchange reaction time for disappearance of $D_{0}$ for the (a) parent molecular ion $[\mathrm{M}+\mathrm{H}]^{+},(\mathbf{b}) \mathrm{b}_{5}{ }^{+}$, and $(\mathbf{c}) \mathrm{b}_{4}{ }^{+}$fragment ions. Insets show the semilog plots $\{$ ln (normalized abundance) versus $\mathrm{H} / \mathrm{D}$ exchange reaction time\} for $(\mathbf{a})[\mathrm{M}+\mathrm{H}]^{+},(\mathbf{b}) \mathrm{b}_{5}{ }^{+}$, and (c) $\mathrm{b}_{4}{ }^{+}$. Segments of the semilog plots in (b) and (c) that correspond to fast- $\left(\mathrm{b}_{5 \mathrm{f}}{ }^{+}\right.$and $\left.\mathrm{b}_{4 \mathrm{f}}{ }^{+}\right)$and slow-exchanging $\left(\mathrm{b}_{5 \mathrm{~s}}{ }^{+}\right.$and $\left.\mathrm{b}_{4 \mathrm{~s}}{ }^{+}\right)$ conformers and/or isomers are labeled with filled circles (" $\mathrm{f}$ " [filled circle]) and open triangles ("s" [open triangle]), respectively. Linear fit of the semilog plots \{excluding the two midway data points labeled with filled square [ $\mathbf{m}]$ in insets of $(\mathbf{b})$ and (c) $\}$ yielded satisfactory results with $\mathrm{R}^{2}>0.99$ for all five fits. two isobaric fragment ions with different reactivity in reaction with $\mathrm{ND}_{3}$. Calculated rate constant for $[\mathrm{M}+\mathrm{H}]^{+}$ is $\sim$ five and 29 times larger than the calculated rate constant values for the $\mathrm{b}_{5 \mathrm{f}}{ }^{+}$and $\mathrm{b}_{5 \mathrm{~s}}{ }^{+}$, respectively. Simi-
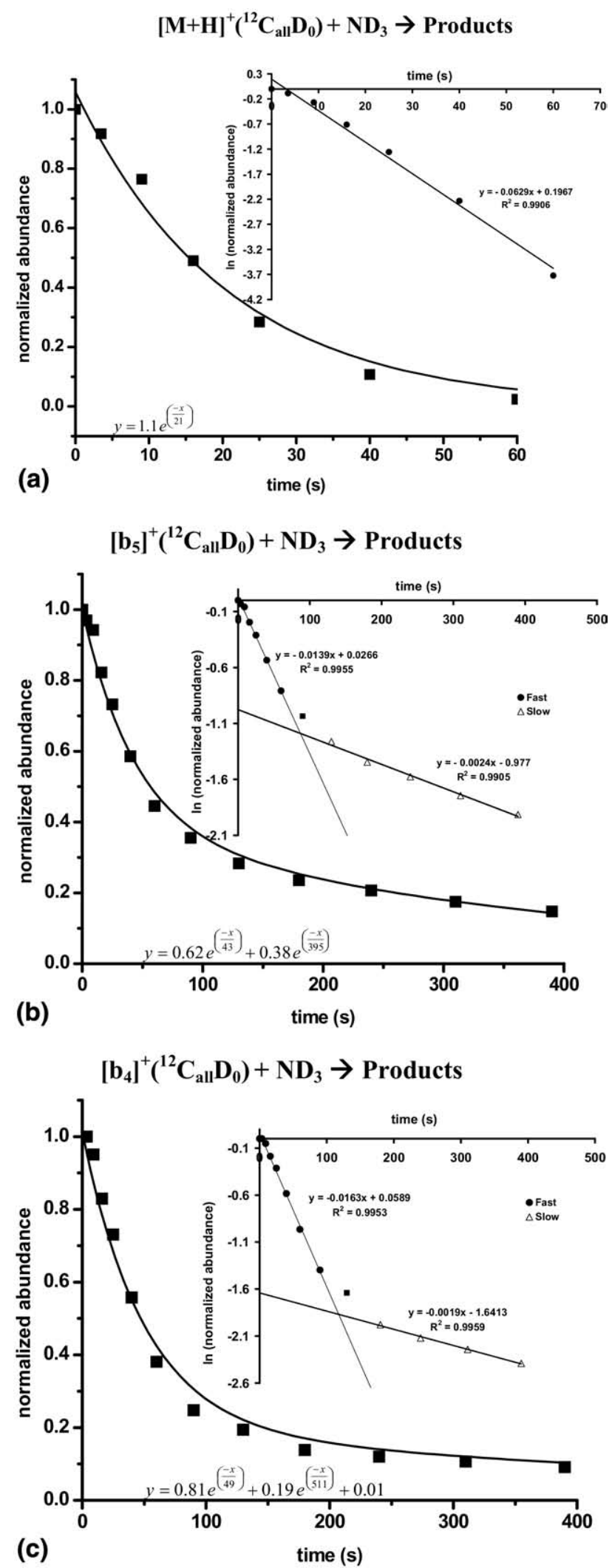
(a)

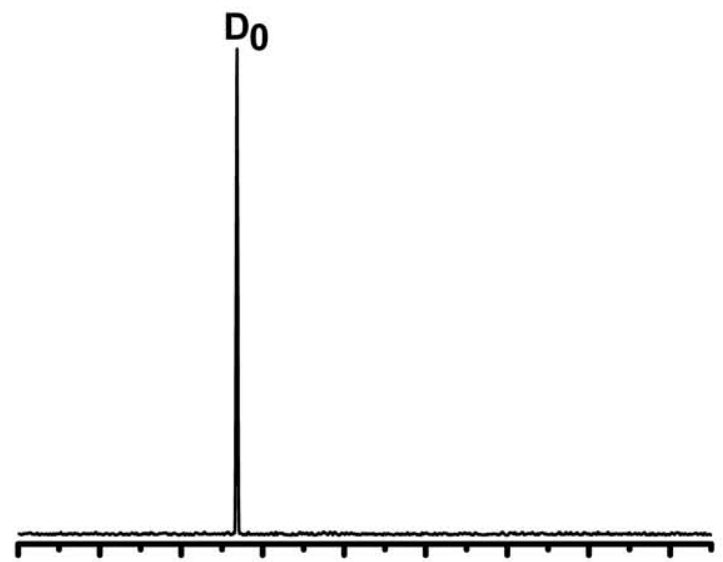

(b)

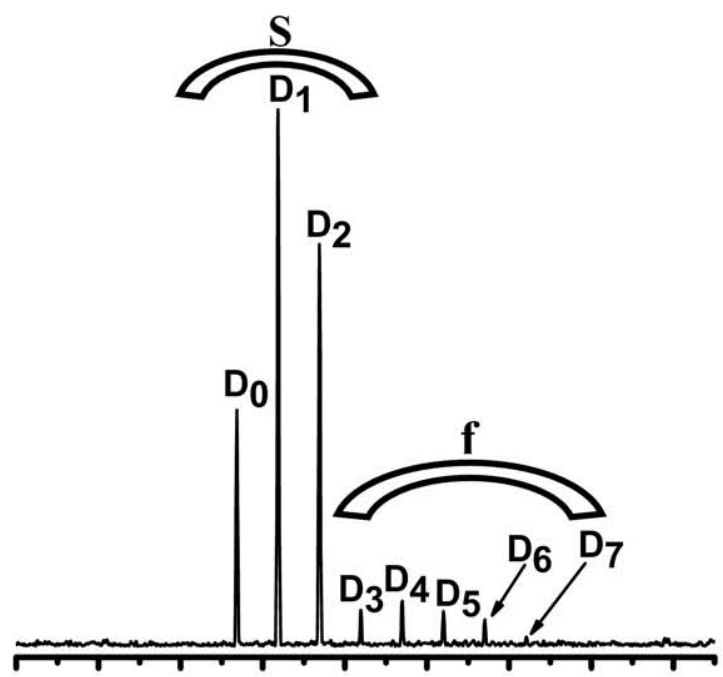

\section{(c)}

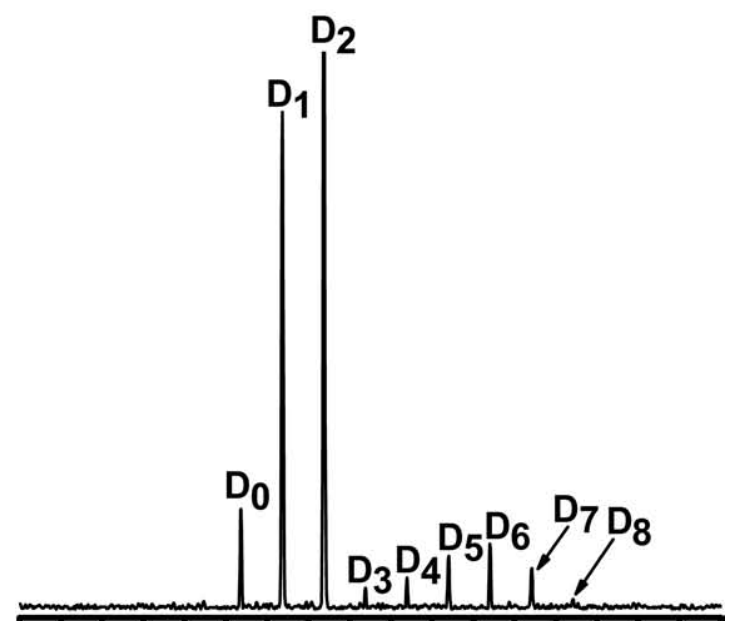

$\begin{array}{llllllllll}746 & 748 & 750 & 752 & 754 & 756 \quad 758 & 760762\end{array}$ $\mathrm{m} / \mathrm{z}$

Figure 4. The fragment ion $\mathrm{b}_{5}{ }^{+}$was (a) SWIFT isolated and (in two separate experiments) reacted and with $\mathrm{ND}_{3}$ (at $\sim 7.5 \times 10^{-8}$ torr) for (b) $40 \mathrm{~s}$ and (c) $300 \mathrm{~s}$. The slow " $\mathrm{s}$ " and fast " $\mathrm{f}$ " exchanging populations are indicated in (b).

larly, calculated rate constant of the parent molecular ion is $\sim$ four and $\sim 32$ times larger than those for the $\mathrm{b}_{4 \mathrm{f}}{ }^{+}$and $\mathrm{b}_{4 \mathrm{~s}}{ }^{+}$, respectively (see Table 1 ). Presence of (a)
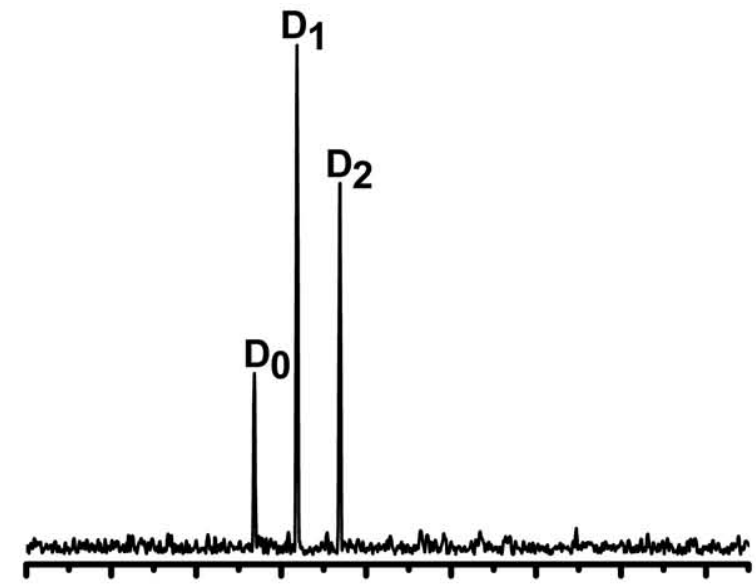

(b)
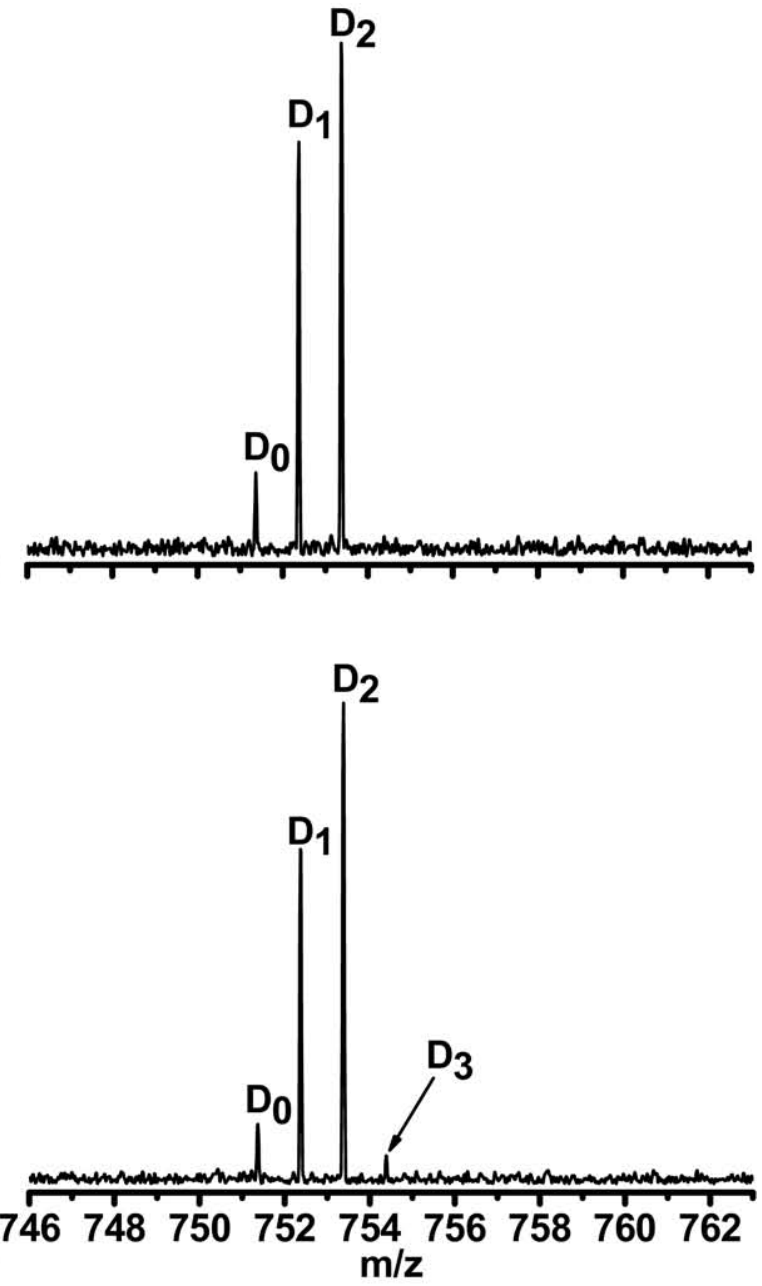

Figure 5. First, all carbon $12\left({ }^{12} \mathrm{C}_{\text {all }}\right)$ isotopes of $\mathrm{b}_{5}{ }^{+}$ions were SWIFT isolated and reacted with $\mathrm{ND}_{3}\left(\sim 7.4 \times 10^{-8}\right.$ torr $)$ for $40 \mathrm{~s}$ to produce the slow and fast H/D exchanging distribution of product ions (not shown). Then, the $\mathrm{b}_{5 \mathrm{f}}{ }^{+}$product ions $\left(\mathrm{D}_{3}-\mathrm{D}_{7}\right.$ series) were ejected to produce the double SWIFT isolated $b_{5 s}{ }^{+}$ series $\left(D_{0}-D_{2}\right.$ series) shown in (a). In the second and third H/D exchange experiments, the SWIFT isolated "s" product ions $\left(\mathrm{b}_{5 \mathrm{~s}}{ }^{+}\right)$ were allowed to react with re-introduced $\mathrm{ND}_{3}\left(\sim 7.0 \times 10^{-8}\right.$ torr in the second and $\sim 7.4 \times 10^{-8}$ torr the third H/D exchange experiment) for additional $90 \mathrm{~s} \mathrm{(b)}$ and $190 \mathrm{~s} \mathrm{(c).}$ 


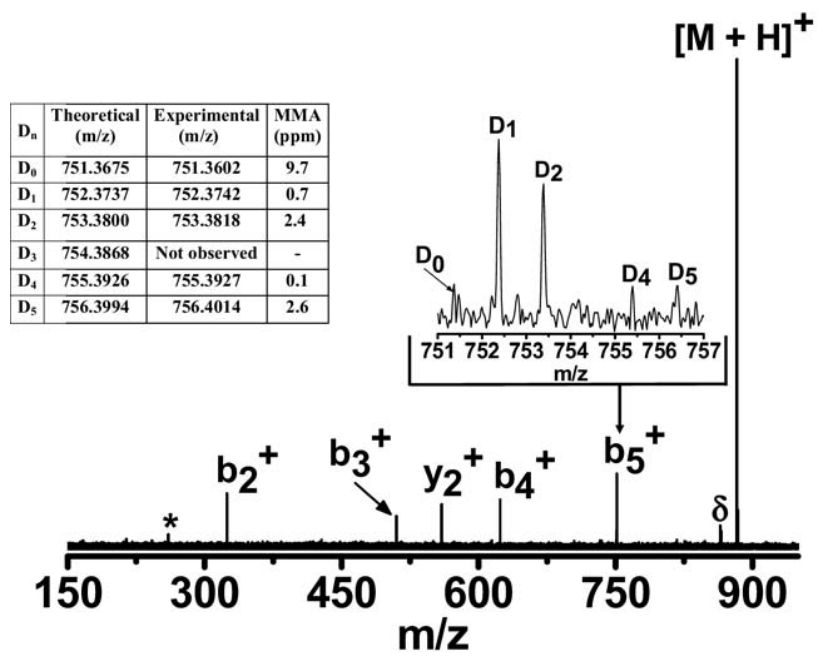

Figure 6. Using SORI-CAD, the SWIFT isolated $\left({ }^{12} \mathrm{C}_{\text {all }}\right)$ of $[\mathrm{M}+$ $\mathrm{H}]^{+}$were fragmented to produce the $\mathrm{b}$-series ions $\left(\mathrm{b}_{5}{ }^{+}, \mathrm{b}_{4}{ }^{+}, \mathrm{b}_{3}{ }^{+}\right.$, and $\mathrm{b}_{2}{ }^{+}$). $\mathrm{ND}_{3}$ was introduced (for $50 \mathrm{~s}$ at $\sim 1.7 \times 10^{-7}$ torr) and product ions were examined to check for the presence of $b_{5 s}{ }^{+}$and $\mathrm{b}_{5 \mathrm{f}}{ }^{+}$. As shown in the panel, the H/D exchange pattern (and calculated mass measurement accuracy) for $\mathrm{H} / \mathrm{D}$ exchange product ions $\mathrm{D}_{1}$, $\mathrm{D}_{2}, \mathrm{D}_{4}$, and $\mathrm{D}_{5}$ confirm that $\mathrm{b}_{5 \mathrm{~s}}{ }^{+}$and $\mathrm{b}_{5 \mathrm{f}}{ }^{+}$are produced under the low-energy CID condition of ICR. Top left panel contains the mass measurement accuracy (MMA) values for the product ions (*: background noise; $\delta:\left[\mathrm{M}+\mathrm{H}-\mathrm{H}_{2} \mathrm{O}\right],\left[\mathrm{M}+\mathrm{H}-\mathrm{NH}_{3}\right]^{+}$).

different $b$ fragment ion conformers/isomers [37] has been confirmed using other analytical techniques, such as IR-MPD [36], ion mobility/mass spectrometry [32, 35], and H/D exchange [31]. Using IR depletion spectrum of $\mathrm{b}_{4}{ }^{+}$fragment (generated by SORI-CAD) of Leu-enkephalin, Polfer et al. detected a mixture of two structurally different $\mathrm{b}_{4}{ }^{+}$ion fragments (i.e., oxazolone and cyclic structures) [36]. Ion mobility/mass spectrometry of Leu-enkephalin $b_{4}{ }^{+}$fragment showed a broader drift time distribution for Leu-enkephalin $\mathrm{b}_{4}{ }^{+}$fragment than $N$-acetylated Leu-enkephalin $\mathrm{b}_{4}{ }^{+}$fragment [32]. It was suggested that the narrow drift time distribution of $\mathrm{N}$-acetylated Leu-enkephalin $\mathrm{b}_{4}{ }^{+}$fragment is related to the presence of bulky $\mathrm{N}$-acetyl group at the N-terminus which prevents the formation of cyclic structure in comparison with Leu-enkephalin [32]. Additional studies are required before reliable comparisons can be made between the observed H/D exchange patterns for different peptide and protein fragments.
In addition to the kinetic studies, we performed double H/D exchange experiments on SWIFT isolated $\mathrm{b}_{5}{ }^{+}$fragment ion to confirm the existence of the two sets of gas-phase fragment ion species. Details of the double $\mathrm{H} / \mathrm{D}$ exchange reactions are discussed in the following sections.

\section{Hydrogen/Deuterium Exchange Reaction Trends}

In a series of experiments, we increased the H/D reaction time from $40 \mathrm{~s}$ up to $300 \mathrm{~s}$ at $\sim 7.5 \times 10^{-8}$ torr $\mathrm{ND}_{3}$ pressure. The $\mathrm{b}_{5}{ }^{+}$fragment ion was first SWIFT isolated (Figure $4 \mathrm{a}$ ) and then reacted with $\mathrm{ND}_{3}$ in two separate experiments. Figure $4 \mathrm{~b}$ and $\mathrm{c}$ show the patterns of the H/D exchange product ions after 40 and $300 \mathrm{~s}$ reaction of the isolated $\mathrm{b}_{5}{ }^{+}$with $\mathrm{ND}_{3}\left(\sim 7.5 \times 10^{-8}\right.$ torr), respectively. After the $40 \mathrm{~s}$ reaction delay, product ions $\left(D_{0}-D_{7}\right)$ are separated into two sets, exhibiting two $\mathrm{H} / \mathrm{D}$ exchange distributions. These slow ("s") and fast (" $\mathrm{f}$ ") $\mathrm{H} / \mathrm{D}$ exchanging sets, in Figure $4 \mathrm{~b}$, include the $\mathrm{D}_{0}-\mathrm{D}_{2}$ ("s") and $\mathrm{D}_{3}-\mathrm{D}_{7}$ (" $\mathrm{f}$ ") product ion series.

As shown in Figure $4 \mathrm{~b}$ and $c$, when the reaction time is increased from $40 \mathrm{~s}$ to $300 \mathrm{~s}$, the relative ion abundance of $D_{0}$ and $D_{1}$ are reduced $\left(D_{0}\right.$ and $D_{1}$ are consumed), whereas the relative ion abundance of $D_{2}$ is increased $\left(\mathrm{D}_{2}\right.$ ions are produced). Conversely, $\mathrm{D}_{3}$ and $D_{4}$ relative ion abundance are reduced $\left(D_{3}\right.$ and $D_{4}$ are on average consumed faster than they can be formed). Note that relative ion abundance of $D_{5}, D_{6}, D_{7}$, and $D_{8}$ ions are increased (these species are formed as $D_{3}$ and $\mathrm{D}_{4}$ are consumed). If the majority of $\mathrm{D}_{2}, \mathrm{D}_{3}$, and $\mathrm{D}_{4}$ species had similar structures (hence $H / D$ exchange characteristics), the increase in relative ion abundance of $\mathrm{D}_{2}$ should be associated with an increase in the relative ion abundance of $\mathrm{D}_{3}$ and $\mathrm{D}_{4}$. As shown in Figure $4 \mathrm{~b}$ and $\mathrm{c}$, increasing the $\mathrm{ND}_{3}$ reaction time from $40 \mathrm{~s}$ to $300 \mathrm{~s}$ results in an increased $\mathrm{D}_{2}$ relative ion abundance but $D_{0}, D_{1}, D_{3}$, and $D_{4}$ relative ion abundance are decreased. These observations, in Figure 4, confirm the existence of two sets of different structures with distinct $\mathrm{H} / \mathrm{D}$ exchange characteristics. After $300 \mathrm{~s}$ reaction with $\mathrm{ND}_{3}\left(\sim 7.5 \times 10^{-8}\right.$ torr), the slow ("s") and fast (" $\mathrm{f}$ ") exchanging $\mathrm{b}_{5}{ }^{+}$species exchange up to two and eight hydrogens (from the total of 11 available labile hydrogens in $b_{5}{ }^{+}$), respectively (Figure $4 b$ and $c$ ). The "s" type species may have more compact/folded structures (probably cyclic structure) and tighter in-

Table 1. Calculated rate constants* $\left(\mathrm{cm}^{3}\right.$ molecule $\left.{ }^{-1} \mathrm{~s}^{-1}\right)$ and relevant parameters for disappearance of $\mathrm{D}_{0}$ for $[\mathrm{M}+\mathrm{H}]^{+}$, fragment ions $b_{5}{ }^{+}$and $b_{4}{ }^{+}$\{fast (" $f$ "), and slow ("s") exchanging species\}. The exact masses, ion population fractions, rate constants (95\% CL), and rate constant ratios are listed in columns $2-5$, respectively

\begin{tabular}{lcccr}
\hline Species x & Exact $m / z$ & Fraction & Rate Constant & $\mathrm{k}_{[\mathrm{M}+\mathrm{H}]}{ }^{+} / \mathrm{k}_{\mathrm{x}}$ \\
\hline \hline$[\mathrm{M}+\mathrm{H}]^{+}$ & 882.46208 & 1.00 & $(3.8 \pm 0.7) \times 10^{-10}$ & 1 \\
${\text { Fast b }{ }_{5}^{+}}^{+}$ & 751.36746 & $0.27 \pm 0.02$ & $(7.7 \pm 1.5) \times 10^{-11}$ & 5 \\
Slow $\mathrm{b}_{5}{ }^{+}$ & 751.36746 & $0.73 \pm 0.02$ & $(1.3 \pm 0.3) \times 10^{-11}$ & 29 \\
Fast b $_{4}^{+}$ & 623.30888 & $0.73 \pm 0.03$ & $(1.0 \pm 0.2) \times 10^{-10}$ & 4 \\
Slow $\mathrm{b}_{4}{ }^{+}$ & 623.30888 & $0.27 \pm 0.03$ & $(1.2 \pm 0.3) \times 10^{-11}$ & 32 \\
\hline
\end{tabular}

*Experimentally measured rate constant ( $n=5$ measurements and at the $95 \%$ confidence level). 
tramolecular hydrogen bondings than unfolded/floppy (probably oxazolone or aziridinone structure) " $\mathrm{f}$ " type fragment ions.

It should be noted that differences in the gas-phase basicities [44] of the " $s$ " and " $f$ " fragments (e.g., proton affinity (PA) variations as a function of structure) may also explain the observed disparate H/D exchange reaction rates [52]. For example, recent theoretical calculations by Bythell et al. at the B3LYP/6-31G(d) level suggest that oxazolone structures may have higher PA values than cyclic forms [39]. Our preliminary PA measurements and $H / D$ exchange results suggest that different populations of singly charged $b_{5}$ fragment ions (of WHWLQL) may have different PA values [50].

\section{Double H/D Exchange Reactions of Doubly SWIFT Isolated Ions}

We performed three complementary double SWIFT isolation and double $\mathrm{H} / \mathrm{D}$ exchange experiments to confirm the presence of unique " $s$ " and " $f$ " $b$ fragment ions. For all SWIFT isolation events sufficient time delay was allowed to remove nitrogen and $\mathrm{ND}_{3}$ reagent gases that were used for ion thermalization and $\mathrm{H} / \mathrm{D}$ exchange reactions. In the first experiment, we SWIFT isolated the ${ }^{12} \mathrm{C}_{\text {all }}$ isotopomers of $\mathrm{b}_{5}{ }^{+}$and then introduced the $\mathrm{ND}_{3}$ reagent gas $\left(\sim 7.4 \times 10^{-8}\right.$ torr $)$ for $40 \mathrm{~s}$ to produce the bimodal ion product distribution. Once the bimodal distribution was formed, we SWIFT isolated the first " $s$ " $\left(D_{0}-D_{2}\right)$ series (i.e., ejected the second " $f$ " $\left\{D_{3}-D_{7}\right\}$ distribution) and acquired a mass spectrum (Figure 5a).
For the double H/D exchange experiments, first we employed a double SWIFT isolation to isolate the " $\mathrm{s}$ " series as described in Figure 5 a (i.e., isolate ${ }^{12} C_{\text {all }}$ of $b_{5}{ }^{+} \rightarrow$ introduce $\mathrm{ND}_{3}$ at the specified pressure and reaction time to produce " $\mathrm{f}$ " and " $\mathrm{s}$ " fragment ions $\rightarrow$ eject the " $f$ " fragment ions). Once the " $s$ " $\left(D_{0}-D_{2}\right)$ series were isolated, the $\mathrm{ND}_{3}$ reagent gas was reintroduced for an additional period of $90 \mathrm{~s}\left(\sim 7.2 \times 10^{-8}\right.$ torr $\mathrm{ND}_{3}$ pressure) to perform a second $\mathrm{H} / \mathrm{D}$ exchange reaction (Figure 5b). As shown in Figure 5b, even after reaction of $b_{5 \mathrm{~s}}{ }^{+}$with $\mathrm{ND}_{3}$ (at $\sim 7.2 \times 10^{-8}$ torr) for an additional $90 \mathrm{~s}$, the second H/D exchange distribution $\left(\mathrm{b}_{5 \mathrm{f}}{ }^{+}\right.$or " $\mathrm{f}$ " series that had initially appeared after the first $40 \mathrm{~s}$ reaction delay) is not observed. This result also confirms that $b_{5}{ }^{+}$ions exist as two $b_{5 s}{ }^{+}$and $b_{5 f}{ }^{+}$structures. After the re-introduction of $\mathrm{ND}_{3}$ for an additional $90 \mathrm{~s}$ $\mathrm{H} / \mathrm{D}$ exchange reaction, the relative ion abundance of $D_{0}$ and $D_{1}$ are reduced, whereas that of $D_{2}$ is increased. These data suggest the presence of strong intramolecular hydrogen bondings within $\mathrm{b}_{5 \mathrm{~s}}{ }^{+}$structure since only two of the 11 labile hydrogens in $\mathrm{b}_{5 \mathrm{~s}}{ }^{+}$are easily available/accessible for the H/D exchange reactions.

In the third double SWIFT isolation, we applied the conditions of the Figure 5 a (i.e., isolate ${ }^{12} \mathrm{C}_{\text {all }}$ of $\mathrm{b}_{5}{ }^{+} \rightarrow$ introduce $\mathrm{ND}_{3}$ at the specified pressure and reaction time to produce " $\mathrm{f}$ " and " $\mathrm{s}$ " fragment ions $\rightarrow$ eject the " $\mathrm{f}$ " fragment ions) followed by a second $\mathrm{ND}_{3}$ reaction delay for $190 \mathrm{~s}$ at $\sim 7.2 \times 10^{-8}$ torr $\mathrm{ND}_{3}$ pressure (Figure 5c). After increasing the $\mathrm{ND}_{3}$ reaction time to $190 \mathrm{~s}$ for the second $H / D$ exchange reaction, a peak at $m / z 754$ $\left(D_{3}\right)$ appears; however, the second H/D exchange distribution is still not observed. Therefore, double SWIFT
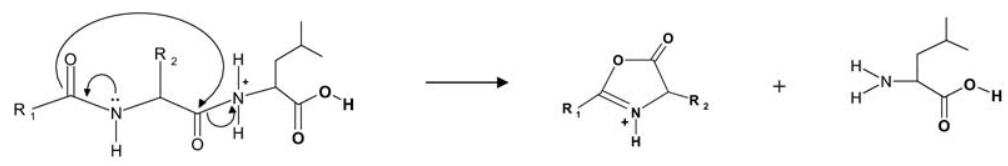

(a) $\lceil\mathrm{M}+\mathrm{H}\rceil^{+}: \mathrm{m} / \mathrm{z} 882.41$

$\mathrm{b}_{5}{ }^{+}: \mathrm{m} / \mathrm{z} 751.32$

Oxazolone structure

Leucine: MW 131.09

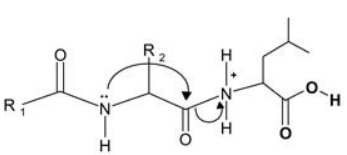

(b)

$\mathrm{rM}+\mathrm{HI}^{+}: \mathrm{m} / \mathrm{z} 882.41$
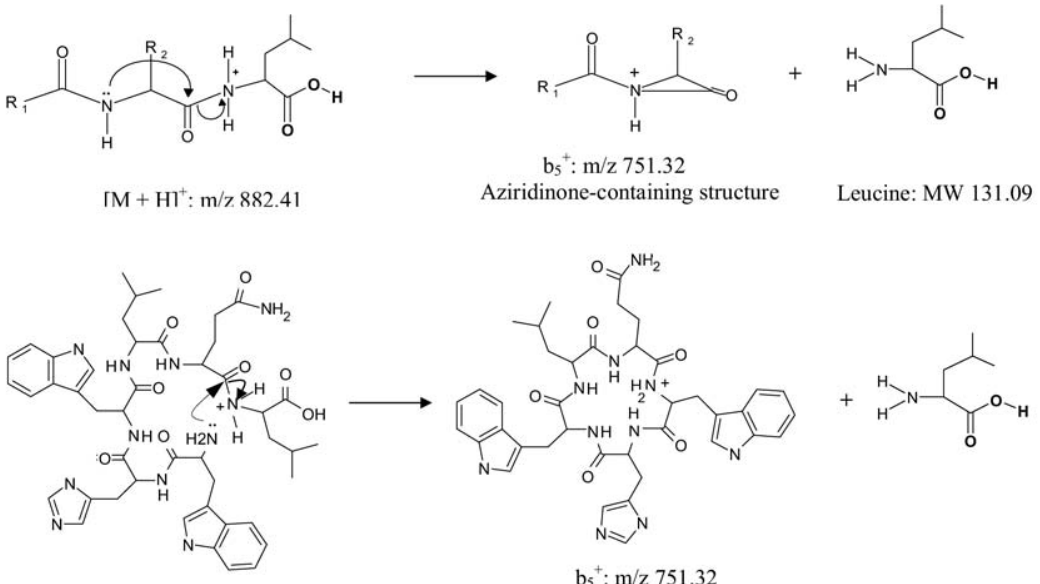

Aziridinone-containing structure

Leucine: MW 131.09

$\mathrm{rM}+\mathrm{HI}^{+}: \mathrm{m} / \mathrm{z} .882 .41$

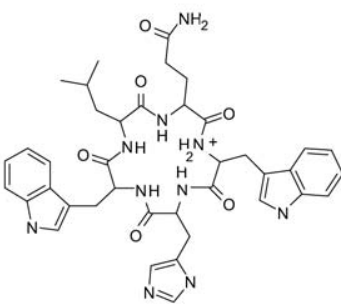

$\mathrm{b}_{5}{ }^{+}: \mathrm{m} / \mathrm{z} 751.32$

Cyclic structure

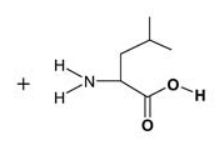

Leucine: MW 131.09

(c) $\mathrm{R}_{1}:$ Trp-His-Trp-CO-NH-CH-, $\mathrm{R}_{2}: \mathrm{NH}_{2}-\mathrm{CO}-\mathrm{CH}_{2}-\mathrm{CH}_{2}-$

Scheme 1 
isolation/double $\mathrm{H} / \mathrm{D}$ exchange reaction of Figure $5 \mathrm{c}$ also confirms the presence of $\mathrm{b}_{5 \mathrm{~s}}{ }^{+}$and $\mathrm{b}_{5 \mathrm{f}}{ }^{+}$structures. To the best of our knowledge, this is the first reported attempt to isolate the slow exchanging $b$ fragment ions using $\mathrm{H} / \mathrm{D}$ exchange time as a filter.

\section{Low-Energy Collision Induced Dissociation of Isolated Parent Ions}

The successful implementation of the complex FT-ICR MS event sequences in previously described double SWIFT isolation and double $\mathrm{H} / \mathrm{D}$ exchange reactions required a large/sufficient number of initial ion population. Ergo, to perform these multi-ejection experiments, it was necessary to optimize the ESI and ICR conditions for the maximal $\mathrm{b}$ fragment ion yield; additional experiments confirmed that majority of the fragment ions were formed in the ESI source. We wanted to determine whether or not significant amounts of the " $s$ " and " $\mathrm{f}$ " conformers/isomers of $\mathrm{b}_{5}{ }^{+}$and $\mathrm{b}_{4}{ }^{+}$were also produced under the low-energy SORI-CAD condition in the ICR cell. In other words, if we exclude the fragment ions generated in the ESI source, will we still observe the two $b_{5 f}{ }^{+}$and $b_{5 s}{ }^{+}$gas-phase fragment ions? To address this question, we performed SORI-CAD of the isolated parent molecular ions $[\mathrm{M}+\mathrm{H}]^{+}(\mathrm{m} / \mathrm{z}$ 882) followed by the $\mathrm{H} / \mathrm{D}$ exchange reactions.

The all carbon 12 isotopes $\left({ }^{12} \mathrm{C}_{\mathrm{all}}\right)$ of $[\mathrm{M}+\mathrm{H}]^{+}$were SWIFT isolated and then fragmented under optimized SORI-CAD experimental conditions (e.g., off resonance at $\sim 1 \mathrm{kHz}<[\mathrm{M}+\mathrm{H}]^{+}$ICR frequency or $\Delta \omega_{\mathrm{c}} \cong 1 \mathrm{kHz}$ with rf excitation $\left\{20 \mathrm{~V}_{p-p}\right\}$ applied for $\sim 50 \mathrm{~ms}$ at $\mathrm{N}_{2}$ pressure of $\sim 1 \times 10^{-6}$ torr). The mass spectrum obtained from SORI-CAD experiment for the SWIFT isolated $[\mathrm{M}+\mathrm{H}]^{+}$is shown in Figure 6. Although the signal-to-noise $(\mathrm{S} / \mathrm{N})$ ratio is low (for example, compared with the results in Figure 4), after $40 \mathrm{~s}$ of H/D exchange reaction with $\mathrm{ND}_{3}\left(\mathrm{P} \sim 7.4 \times 10^{-8}\right.$ torr $)$, the two $b_{5 f}{ }^{+}$and $b_{5 s}{ }^{+}$type fragment ions can be observed (see inset mass spectrum in Figure 6).

The inset in Figure 6 shows the $m / z$ region $(751-757)$ for $\mathrm{H} / \mathrm{D}$ exchange reaction product ions of the $\mathrm{b}_{5}{ }^{+}$(the $\mathrm{H} / \mathrm{D}$ exchange pattern for the other fragment ions are not shown). The H/D exchange pattern of $\mathrm{b}_{5}{ }^{+}$exhibits two $\mathrm{H} / \mathrm{D}$ exchange distributions implying the existence of $\mathrm{b}_{5 \mathrm{f}}{ }^{+}$and $\mathrm{b}_{5 \mathrm{~s}}{ }^{+}$under the low-energy SORI-CAD conditions of the ICR. Poor signal-to-noise $(\mathrm{S} / \mathrm{N})$ ratio in Figure 6 inset signifies that monitoring the H/D exchange of $b$ fragment ions after SWIFT isolation and SORI-CAD of $[\mathrm{M}+\mathrm{H}]^{+}$, requires a large initial ion population. Fortunately, unsurpassed mass measurement accuracy (MMA) of FT-ICR allows product ion identification, even when $S / N$ ratio of the single scan mass spectrum is very poor $\left(S / N \sim 2.5\right.$ for $D_{0}, D_{4}$, and $\mathrm{D}_{5}$ in Figure 6 inset). To assign the product ion identities, we used the exact masses of observed fragment ions $\left(D_{1}\right.$ ions from $b_{4}{ }^{+}, b_{3}{ }^{+}$, and $\left.b_{2}{ }^{+}\right)$and $D_{1}$ from H/D exchange product of $\mathrm{b}_{5}{ }^{+}$as internal calibrants. Utilizing experimental mass measurement accuracy of below 10 ppm, $D_{0}$ and $H / D$ exchange product ions $\left(D_{2}, D_{4}\right.$, and $\mathrm{D}_{5}$ ) of $\mathrm{b}_{5}{ }^{+}$can be readily distinguished from the background noise. The theoretical and experimental $\mathrm{m} / \mathrm{z}$ values of the $D_{0}, D_{1}, D_{2}, D_{4}$, and $D_{5}$ are shown in the top-left panel of Figure 6. The observed mass measurement accuracies for $\mathrm{D}_{0}, \mathrm{D}_{1}, \mathrm{D}_{2}, \mathrm{D}_{4}$, and $\mathrm{D}_{5}$, were $9.7,0.7$, $2.4,0.1$, and $2.6 \mathrm{ppm}$, respectively (top-left panel of Figure 6). The background noise and $[\mathrm{M}+\mathrm{H}-$ $\left.\mathrm{H}_{2} \mathrm{O} / \mathrm{NH}_{3}\right]^{+}$peaks in Figures 6 are labeled with ${ }^{*}$ and $\delta$ symbols, respectively.

A significant amount of literature has focused on various aspects of b fragment ion structures [19-21, 23-28]. The present results suggest that there could be more than one reaction pathways leading to $b$ fragment ion formation. Such multiple reaction pathways may be involved in other types of ion fragmentations, and future research will address these questions. Preliminary $H / D$ exchange results from our laboratory suggest that other $b$ fragment ions (e.g., doubly charged $b_{10}$ fragment ions of substance $\mathrm{P}$ and singly charged $b_{5}$ fragment ions of $\alpha$-melanocyte) show similar bimodal H/D exchange distributions. Polfer's group also reported a bimodal H/D exchange distribution for $b$ fragment ions of $(\mathrm{Gly})_{\mathrm{n}}$ [31]. These results confirm our original observation on $b$ fragment ion $H / D$ exchange bimodal distributions for delta sleep inducing hormone DSIP and WHWLQL hexapeptide [37]. Moreover, we have been able to observe these bimodal H/D exchange distribution on larger fragment ions (e.g., doubly charged fragment ions of substance P) [50]. Hence, fundamental understanding of $b$ fragment ion formations is important and might have a global impact on the peptide and protein sequencing. In the following section, we discuss various possible mechanisms for $b$ fragment ion formation.

\section{Possible Mechanisms for Formation of Different $b$ Fragment Ions}

Some of the plausible mechanisms for formation of $\mathrm{b}_{5}{ }^{+}$ fragment ions from $[\mathrm{M}+\mathrm{H}]^{+}$(the protonated form of the WHWLQL hexapeptide) are shown in Scheme 1. Scheme 1a shows the formation of a five-membered cyclic intermediate that can lead to $b$ fragment ion formation having oxazolone type structure [19-21, 53]. Scheme $\mathbf{1 b}$ shows the production of $b$-series fragment ions via a stable aziridinone (three-membered cyclic amide) structure. Involvement of stable aziridinonecontaining structures in the gas-phase fragmentation of peptides has been demonstrated experimentally [25] and theoretically [26]. Additional theoretical calculations and experimental evidence are needed to address the plausibility of various pathways. For example, theoretical calculations suggest that dissociation of protonated dipeptides go thorough the ' $\mathrm{a}_{1}-\mathrm{y}_{1}$ ' pathway, which is much faster and energetically more favored than the 'aziridinone' pathway [30]. A majority of the previous 
theoretical work suggests that it is unlikely for the $b$ ions to have the aziridinone structure, although the WHWLQL hexapeptide contains both histidine and glutamine and the nucleophile side chains of these residues may be responsible for the $b_{x}$ isomers. Another possible structure for $b_{5}{ }^{+}$is a cyclic structure that can be formed through the mechanism shown in Scheme 1c. The cyclic structure for b-type fragments has been proposed recently by different research groups $[18,31$, 32]. It has been suggested that subsequent fragmentation of cyclic b-type fragments can result in the sequence scrambling of protein/peptide and, therefore, loss of original protein/peptide sequence information [17]. Therefore, the understanding of different ion fragmentation pathways can improve/accelerate the protein/peptide sequencing in proteomics.

Although in Scheme $\mathbf{1}$ we only include three pathways for formation of isobaric $b$ fragment ions, other options are also possible [24, 29]. Recent theoretical studies suggest that a majority of the sequence-informative fragment ions of protonated tripeptides may be formed on the ' $b_{x}-y_{z}{ }^{\prime}$ pathway [24]. Additional experimental and theoretical studies are required to assign the structures of the observed isobaric fragment ions and determine accurate fragmentation pathways. The $\mathrm{H} / \mathrm{D}$ exchange results clearly demonstrate that isobaric fragment ions of peptides may exist as different conformer/isomers; these findings are crucial for understanding the molecular details of peptide and protein sequencing.

\section{Conclusion}

Drastically different H/D exchange trends were observed for WHWLQL and its $\mathrm{b}_{5}{ }^{+}$and $\mathrm{b}_{4}{ }^{+}$fragment ions; these variations point to the existence of different gas-phase conformers/isomers of $b_{5}{ }^{+}$and $b_{4}{ }^{+}$. Both $b_{5}{ }^{+}$ and $\mathrm{b}_{4}{ }^{+}$fragment ions of WHWLQL yielded bimodal distributions of $\mathrm{H} / \mathrm{D}$ exchanged product ions after $580 \mathrm{~s}$ reaction delay with $\mathrm{ND}_{3}\left(\mathrm{P} \cong 6.5 \times 10^{-9}\right.$ torr $)$. The plots of $\ln$ (normalized abundance) versus reaction time for $\mathrm{b}_{5}{ }^{+}$and $\mathrm{b}_{4}{ }^{+}$exhibited two distinctly different slopes. The kinetic data confirmed the presence of two different isomers/conformers for $b_{5}{ }^{+}$and $b_{4}{ }^{+}$fragment ions of WHWLQL. Under identical experimental conditions, plot of $\ln$ (normalized abundance) versus H/D exchange reaction time for parent molecular ion showed only one slope. A single slope suggests the presence of parent molecular ions as a single gas-phase conformer or set of conformers that can not be resolved under the present FT-ICR H/D experimental conditions.

The results from this study illustrate that parent molecular ions of biomolecules can dissociate to produce isobaric fragment ions as different conformers and/or isomers. Other experimental approaches, such as ion mobility and cross section measurements [7, 54-57], should provide complementary structural details and additional information on relative differences between the different " $\mathrm{f}$ " and " $\mathrm{s}$ " isomers/conformers.

Successful biomolecular sequencing requires de- tailed understanding of ion fragmentation mechanisms, and $\mathrm{H} / \mathrm{D}$ exchange reactions offer a practical approach to study ion fragmentation processes. Future experimental and theoretical studies of carefully designed model compounds should provide the necessary data for deciphering the details of various ion fragmentation mechanisms.

\section{Acknowledgments}

The authors acknowledge supports for this work in parts by the University of Maine, Orono, Maine (UM5-4-26,157), the Institute for Therapeutic Discovery, and Defense Advanced Research Projects Agency (grant DARPA-N65236-98-1-5415).

\section{References}

1. Loo, J. A.; Loo, R. R. O.; Udseth, H. R.; Edmonds, C. G.; Smith, R. D. Solvent-Induced Conformational Changes of Polypeptides Probed by Electrospray Ionization-Mass Spectrometry. Rapid Commun. Mass Spectrom. 1991, 5, 101-105.

2. Winger, B. E.; Light-Wahl, K. J.; Rockwood, A. L.; Smith, R. D. Probing Qualitative Conformation Differences of Multiply Protonated GasPhase Proteins via H/D Isotopic Exchange with $\mathrm{D}_{2} \mathrm{O}$. J. Am. Chem. Soc. 1992, 114, 5897-5898.

3. Suckau, D.; Shi, Y.; Beu, S. C.; Senko, M. W.; Quinn, J. P.; Wampler-III, F. M.; McLafferty, F. W. Coexisting Stable Conformations of Gaseous Protein Ions. Proc. Natl. Acad. Sci. U.S.A. 1993, 90, 790-793.

4. Gard, E.; Willard, D.; Bregar, J.; Green, M. K.; Lebrilla, C. B. Site Specificity on the H-D Exchange Reactions of Gas-Phase Protonated Amino Acids with $\mathrm{CH}_{3} \mathrm{OD}$. Org. Mass Spectrom. 1993, 28, 1632-1639.

5. Katta, V.; Chait, B. T. Hydrogen/Deuterium Exchange Electrospray Ionization Mass Spectrometry: A Method for Probing Protein Conformational Changes in Solution. J. Am. Chem. Soc. 1993, 115, 6317-6321.

6. Gross, D. S.; Schnier, P. D.; Rodrigues-Cruz, S. E.; Fagerquist, C. K.; Williams, E. R. Conformations and Folding of Lysozyme Ions In Vacuo. Proc. Natl. Acad. Sci. U.S.A. 1996, 93, 3143-3148.

7. Valentine, S. J.; Clemmer, D. E. H/D Exchange Levels of ShapeResolved Cytochrome $c$ Conformers in the Gas Phase. J. Am. Chem. Soc. 1997, 119, 3558-3566.

8. McLafferty, F. W.; Guan, Z.; Haupts, U.; Wood, T. W.; Kelleher, N. L. Gaseous Conformational Structures of Cytochrome c. J. Am. Chem. Soc. 1998, 120, 4732-4740.

9. Veenstra, T. D.; Johnson, K. L.; Tomlinson, A. J.; Craig, T. A.; Kumar, R.; Naylor, S. Zinc-Induced Conformational Changes in the DNA-Binding Domain of the Vitamin D Receptor Determined by Electrospray Ionization Mass Spectrometry. J. Am. Soc. Mass Spectrom. 1998, 9, 8-14.

10. Eyles, S. J.; Speir, J. P.; Kruppa, G. H.; Gierasch, L. M.; Kaltashov, I. A. Protein Conformational Stability Probed by Fourier Transform Ion Cyclotron Resonance Mass Spectrometry. J. Am. Chem. Soc. 2000, 122, 495-500.

11. Freitas, M. A.; Hendrickson, C. L.; Emmett, M. R.; Marshall, A. G. Gas-Phase Bovine Ubiquitin Cation Conformations Resolved by GasPhase Hydrogen/Deuterium Exchange Rate and Extent. Int. J. Mass Spectrom. 1999, 185/186/187, 565-575.

12. Solouki, T.; Fort, R.; Alomary, A.; Fattahi, A. Gas-Phase Hydrogen/ Deuterium Exchange Reactions of a Model Meptide: FT-ICR and Computational Analyses of Metal Induced Conformational Mmutations. J. Am. Soc. Mass Spectrom. 2001, 12, 1272-1285.

13. Gauthier, J. W.; Trautman, T. R.; Jacobson, D. B. Sustained OffResonance Irradiation for Collision-Activated Dissociation Involving Fourier Transform Mass Spectrometry. Collision-Activated Dissociation Technique That Emulates Infrared Multiphoton Dissociation. Anal. Chim. Acta 1991, 246, 211-225.

14. Zubarev, R. A.; Kelleher, N. L.; McLafferty, F. W. Electron Capture Dissociation of Multiply Charged Protein Cations. A Nonergodic Process. J. Am. Chem. Soc. 1998, 120, 3265-3266.

15. Roepstorff, P.; Fohlman, J. Proposal for a Common Nomenclature for Sequence Ions in Mass Spectra of Peptides. Biomed. Mass Spectrom. 1984, 11,601 .

16. Harrison, A. G.; Young, A. B.; Bleiholder, C.; Suhai, S.; Paizs, B. Scrambling of Sequence Information in Collision-Induced Dissociation of Peptides. J. Am. Chem. Soc. 2006, 128, 10364-10365.

17. Harrison, A. G. Peptide Sequence Scrambling Through Cyclization of $b_{5}$ Ions. J. Am. Soc. Mass Spectrom. 2008, 19, 1776-1780.

18. Jia, C.; Qi, W.; He, Z. Cyclization Reaction of Peptide Fragment Ions During Multistage Collisionally Activated Decomposition: An Inducement to Lose Internal Amino-Acid Residues. J. Am. Soc. Mass Spectrom. 2007, 18, 663-678.

19. Arnott, D.; Kottmeier, D.; Yates, N.; Shabanovitz, J.; Hunt, D. F. Fragmentation of Multiply Protonated Peptides Under Low Energy 
Conditions. Proceedings of the 42nd ASMS Conference on Mass Spectrometry and Allied Topics; Chicago, IL, May 29-June 3, 1994; p. 470.

20. Yalcin, T.; Khouw, C.; Csizmadia, I. G.; Peterson, M. R.; Harrison, A. G. Why are b Ions Stable Species in Peptide Spectra? J. Am. Soc. Mass Spectrom. 1995, 6, 1165-1174.

21. Yalcin, T.; Csizmadia, I. G.; Peterson, M. R.; Harrison, A. G. The Structure and Fragmentation of $\mathrm{B}_{n}(n \geq 3)$ Ions in Peptide Spectra. J. Am. Soc. Mass Spectrom. 1996, 7, 233-242.

22. Paizs, B.; Lendvay, G.; Vékey, K.; Suhai, S. Formation of $b_{2}{ }^{+}$Ions from Protonated Peptides: An Ab Initio Study. Rapid Commun. Mass Spectrom. $1999,13,525-533$

23. Schlosser, A.; Lehmann, W. D. Five-Membered Ring Formation in Unimolecular Reactions of Peptides: A Key Structural Element Controlling Low-Energy Collision-Induced Dissociation of Peptides. J. Mass Spectrom. 2000, 35, 1382-1390.

24. Paizs, B.; Suhai, S. Combined Quantum Chemical and RRKM Modeling of the Main Fragmentation Pathways of Protonated GGG. II. Formation of $\mathrm{b}_{2}, \mathrm{y}_{1}$, and $\mathrm{y}_{2}$ Ions. Rapid Commun. Mass Spectrom. 2002, 16, 375-389.

25. Ngoka, L. C. M.; Gross, M. L. Location of Alkali Metal Binding Sites in Endothelin A Selective Receptor Antagonists, Cyclo(D-Trp-D-Asp-ProD-Val-Leu) and Cyclo(D-Trp-D-Asp-Pro-D-Ile-Leu), from Multistep Collisionally Activated Decompositions. J. Mass Spectrom. 2000, 35, 265-276.

26. Klassen, J. S.; Kebarle, P. Collision-Induced Dissociation Threshold Energies of Protonated Glycine, Glycinamide, and Some Related Small Peptides and Peptide Amino Amides. J. Am. Chem. Soc. 1997, 119, 6552-6563.

27. Nold, M. J.; Cerda, B. A.; Wesdemiotis, C. Proton Affinities of the Nand C-Terminal Segments Arising Upon the Dissociation of the Amide Bond in Protonated Peptides. J. Am. Soc. Mass Spectrom. 1999, 10, 1-8.

28. Polce, M. J.; Ren, D.; Wesdemiotis, C. Dissociation of the Peptide Bond in Protonated Peptides. J. Mass Spectrom. 2000, 35, 1391-1398.

29. Paizs, B.; Suhai, S. Combined Quantum Chemical and RRKM Modeling of the Main Fragmentation Pathways of Protonated GGG. I. Cis-trans Isomerization Around Protonated Amide Bond. Rapid Commun. Mass Spectrom. 2001, 15, 2307-2323.

30. Paizs, B.; Suhai, S. Theoretical Study of the Main Fragmentation Pathways for Protonated Glycylglycine. Rapid Commun. Mass Spectrom. 2001, 15, 651-663.

31. Chen, X.; Powell, D. H.; Polfer, N. Fragment Structures in CollisionInduced Dissociation of Peptides Investigated by H/D Exchange. Proceedings of the 56th ASMS Conference on Mass Spectrometry and Allied Topics; Denver, CO, May 31-June 4, 2008; MPMM 334.

32. Polfer, N. C.; Bohrer, B. C.; Plasencia, M. D.; Paizs, B.; Clemmer, D. E. On the Dynamics of Fragment Isomerization in Collision-Induced Dissociation of Peptides. J. Phys. Chem. A 2008, 112, 1286-1293.

33. Paizs, B.; Suhai, S. Fragmentation Pathways of Protonated Peptides. Mass Spectrom. Rev. 2005, 24, 508-548.

34. Fattahi, A.; Solouki, T. Comparison of Conformational Variations Induced by Metal Complexation and b Type Fragmentation for Peptides with Acidic- and Basic-Side Chains: Gas-Phase H/D Exchange Kinetic Studies. Proceedings of the 51st ASMS Conference on Mass Spectrometry and Allied Topics; Montreal, QC, Canada, 2003; ThPK2 199.

35. Riba-Garcia, I.; Giles, K.; Bateman, R. H.; Gaskella, S. J. Evidence for Structural Variants of a- and b-Type Peptide Fragment Ions Using Combined Ion Mobility/Mass Spectrometry. J. Am. Soc. Mass Spectrom. 2008, 19, 609-613.

36. Polfer, N. C.; Oomens, J.; Suhai, S.; Paizs, B. Infrared Spectroscopy and Theoretical Studies on Gas-Phase Protonated Leu-Enkephalin and Its Fragments: Direct Experimental Evidence for the Mobile Proton. J. Am. Chem. Soc. 2007, 129, 5887-5897.

37. Fattahi, A.; Solouki, T. Conformational Analysis of Metal Complexed Model Peptides and Their Fragment Ions Using FT-ICR MS and Gas-Phase H/D Exchange Reactions. Proceedings of the 49th ASMS Conference on Mass Spectrometry and Allied Topics; Chicago, IL, May 27-31, 2001; WPE 102
38. Arehart, E.; Fattahi, A.; Patterson, H.; Solouki, T. Fluorescence Quenching, Mass Spectral H/D Exchange, and Ion Fragmentation Studies of Trp-His-Trp-Leu-Gln-Leu Upon Metal Complexation. Proceedings of the 224th American Chemical Society (ACS) National Meeting; Boston, MA, 2002.

39. Bythell, B. J.; Somogyi, Á.; Paizs, B. What is the Structure of $b_{2}$ Ions Generated from Doubly Protonated Tryptic Peptides? J. Am. Soc. Mass Spectrom. 2009, 20(4), 618-624.

40. Stemmler, E. A.; Yoshida, E.; Pacheco, J.; Brunton, J.; Woodbury, E. Solouki, T. Reactions of $\mathrm{O}^{-}$. with Methyl Benzoate: A Negative Ion Chemical Ionization and Fourier Transform Ion Cyclotron Resonance Study. I. Am. Soc. Mass Spectrom. 2001, 12, 694-706.

41. Comisarow, M. B.; Marshall, A. G. Frequency-Sweep Fourier Transform Ion Cyclotron Resonance Spectroscopy. Chem. Phys. Lett. 1974, 26, 489-490.

42. Wang, T. C. L.; Ricca, T. L.; Marshall, A. G. Extension of Dynamic Range in Fourier Transform Ion Cyclotron Resonance Mass Spectrometry via Stored Waveform Inverse Fourier Transform Excitation. Anal. Chem. 1986, 58, 2935-2938.

43. Jiao, C. Q.; Ranatunga, D. R. A.; Vaughn, W. E.; Freiser, B. S. A Pulsed-Leak Valve for Use with Ion Trapping Mass Spectrometers. J. Am. Soc. Mass Spectrom. 1996, 7, 118-122.

44. Solouki, T.; Szulejko, J. E. Bimolecular and Unimolecular Contributions to the Disparate Self-Chemical Ionizations of $\alpha$-Pinene and Camphene Isomers. J. Am. Soc. Mass Spectrom. 2007, 18, 2026-2039.

45. Morris, M.; Thibault, P.; Boyd, R. K. Low-Energy Ion/Molecule Products from Collisions with Ammonia. Rapid Commun. Mass Spectrom. 1993, 7, 1136-1140.

46. Ausloos, P.; Lias, S. G. Thermoneutral Isotope Exchange Reactions of Cations in the Gas Phase. J. Am. Chem. Soc. 1981, 103, 3641-3645.

47. Campbell, S.; Rodgers, M. T.; Marzluff, E. M.; Beauchamp, J. L. Deuterium Exchange Reactions as a Probe of Biomolecule Structure. Fundamental Studies of Gas Phase H/D Exchange Reactions of Protonated Glycine Oligomers with $\mathrm{D}_{2} \mathrm{O}, \mathrm{CD}_{3} \mathrm{OD}, \mathrm{CD}_{3} \mathrm{CO}_{2} \mathrm{D}$, and $\mathrm{ND}_{3}$. J. Am Chem. Soc. 1995, 117, 12840-12854.

48. Solouki, T.; Freitas, M. A.; Alomary, A. Gas-Phase Hydrogen/ Deuterium Exchange Reactions of Fulvic Acids: An Electrospray Ionization Fourier Transform Ion Cyclotron Resonance Mass Spectral Study. Anal. Chem. 1999, 71, 4719-4726.

49. Alomary, A.; Solouki, T.; Patterson, H. H.; Cronan, C. S. Elucidation of Aluminum-Fulvic Acid Interactions by Gas-Phase Hydrogen/ Deuterium (H/D) Exchange and Electrospray Fourier Transform Ion Cyclotron Resonance Mass Spectrometry (ESI FT-ICR). Environ. Sci. Technol. 2000, 34, 2830-2838

50. Zekavat, B.; Al-Fdeilat, A. H.; Solouki, T. Gas-Phase Basicity Measurements of Singly- and Doubly-Charged bn Fragment Ions Using ESI/FTICR MS. Proceedings of the 57th ASMS Conference on Mass Spectrometry and Allied Topics; Philadelphia, PA, 2009; TP 357.

51. He, F.; Marshall, A. G. Weighted Quasi-Newton and Variable-Order Variable-Step Adams Algorithm for Determining Site-Specific Reaction Rate Constants. J. Phys. Chem. A 2000, 104, 562-567.

52. Green, M. K.; Gard, E.; Bregar, J.; Lebrilla, C. B. H-D Exchange Kinetic of Alcohols and Protonated Peptides: Effects of Structure and Proton Affinity. J. Mass Spectrom. 1995, 30, 1103-1110.

53. Vaisar, T.; Urban, J. Low-Energy Collision Induced Dissociation of Protonated Peptides. Importance of an Oxazolone Formation for a Peptide Bond Cleavage. J. Eur. Mass Spectrom. 1998, 4, 359-364.

54. Clemmer, D. E.; Jarrold, M. F. Ion Mobility Measurements and Their Applications to Clusters and Biomolecules. J. Mass Spectrom. 1997, 32, 577-592.

55. Wyttenbach, T.; Batka-Jr., J. J.; Gidden, J.; Bowers, M. T. Host/Guest Conformations of Biological Systems: Valinomycin/Alkali Ions. Int. J. Mass Spectrom. 1999, 193, 143-152.

56. Ruotolo, B. T.; Verbeck, G. F.; Thomson, L. M.; Gillig, K. J.; Russell, D. H. Observation of Conserved Solution-Phase Secondary Structure in GasPhase Tryptic Peptides. J. Am. Chem. Soc. 2002, 124, 4214-4215.

57. Collins, D. C.; Lee, M. L. Developments in Ion Mobility SpectrometryMass Spectrometry. Anal. Bioanal. Chem. 2002, 372, 66-73. 